
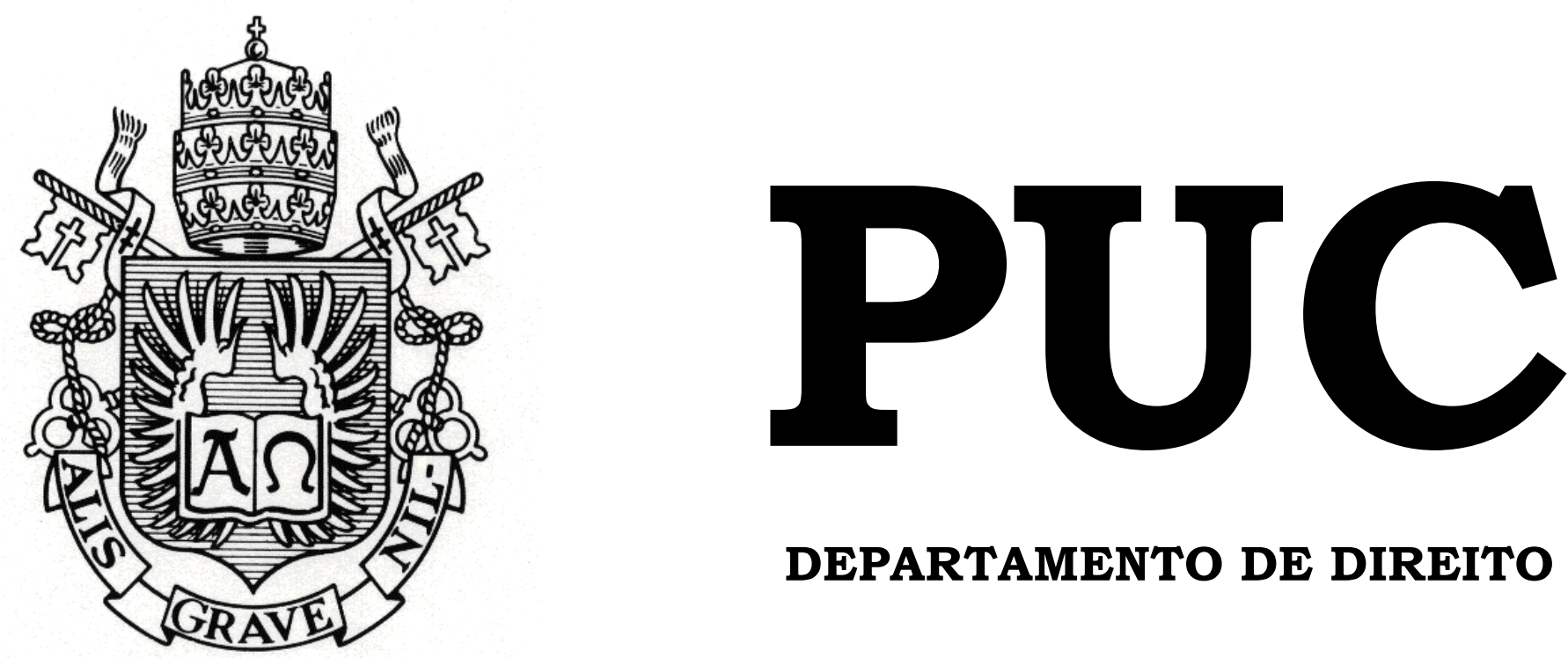

DEPARTAMENTO DE DIREITO

\title{
PROCESSO DELIBERATIVO NO SUPREMO TRIBUNAL FEDERAL: TOMADA DE DECISÃO, FUNDAMENTAÇÃO E DELIBERAÇÃO PARA A FORMAÇÃO DE PRECEDENTES
}

por

CARLA SERTÃ PADILHA

ORIENTADOR: Prof. Fábio Carvalho Leite 2018.1

PONTIFÍCIA UNIVERSIDADE CATÓLICA DO RIO DE JANEIRO RUA MARQUÊS DE SÃO VICENTE, 225 - CEP 22453-900 RIO DE JANEIRO - BRASIL 


\title{
PROCESSO DELIBERATIVO NO
}

SUPREMO TRIBUNAL FEDERAL:

TOMADA DE DECISÃO,

FUNDAMENTAÇÃO E DELIBERAÇÃO

PARA A FORMAÇÃO DE

PRECEDENTES

\author{
por
}

CARLA SERTÃ PADILHA

Monografia

apresentada

ao

Departamento de Direito da

Pontificia Universidade Católica do

Rio de Janeiro (PUC-Rio) como requisito parcial para obtenção do título de Bacharel em Direito.

Orientador: Prof. Fábio Carvalho Leite 


\section{Agradecimentos}

Agradeço a todos, familiares e amigos, que me ajudaram a concluir essa etapa da minha vida, com apoio, conselho e carinho.

Em especial, agradeço a Deus, pelas inúmeras graças e bênçãos concedidas na minha vida e por me guiar sempre nas minhas escolhas pessoais e profissionais.

Agradeço também aos meus pais, Martha e Marcelo, pelo exemplo de amor, determinação e perseverança que sempre foram e por toda a educação que passaram a mim e às minhas irmãs. Às minhas irmãs, Maria e Luiza, e meus cunhados, Fabio e Michel, por serem uma constante presença de apoio e carinho. Ao meu namorado, Emanuel, por estar sempre ao meu lado, oferecendo palavras e silêncio e dando-me forças para seguir em frente.

Aos meus avós, Tarcísio e Ruth, Pedro Paulo e Rosário, cujas sabedoria e trajetória de vida representam, para mim, eterna fonte de inspiração.

Por fim, agradeço a todos os professores que tive tanto na escola quanto na faculdade, em especial ao Professor Fábio Leite, pelas orientações e pelo suporte transmitido ao longo da produção dessa monografia. 


\section{Resumo}

À medida que a atuação do STF ganhou maior projeção em meio à sociedade brasileira, aumentou o número de estudos acerca do processo deliberativo do Tribunal, abarcando tanto a atuação individual de seus Ministros quanto a atividade de seus órgãos colegiados. A partir da psicologia experimental, análises do processo de tomada de decisão jurídica indicam a possibilidade de um magistrado formar seu convencimento com base em atalhos da intuição, utilizando fundamentos jurídicos apenas para justificar a posição previamente adotada. Já os estudos voltados à deliberação colegiada evidenciam que o STF adota práticas incompatíveis com um ideal de corte deliberativa, como o individualismo do relator e dos demais Ministros e a ausência de diálogo entre os votos. Isso implica a dispersão de fundamentos nos acórdãos do STF, dificultando a identificação da ratio decidendi de suas decisões e, consequentemente, a aplicação dos precedentes formados. O STF só será uma corte efetivamente deliberativa quando os seus membros assumirem o compromisso com a instituição, apresentando votos que dialoguem entre si, pautando-se nas bases delineadas pelo relator e preocupando-se em formar uma maioria relativa à fundamentação, deliberando acerca da tese decisória. Esse compromisso deve envolver também a abertura de mudar seu próprio posicionamento a partir dos debates entre os julgadores, em prol da colegialidade.

Palavras-chave: STF; Tomada de decisão; Fundamentação; Deliberação; Colegialidade; Ratio decidendi. 


\section{Sumário}

Introdução .......................................................................................................................6 6

Capítulo 1 - Tomada de decisão e fundamentação dos votos pelos Ministros ......................................................................................................... 9

1.1. Influência das intuições na tomada de decisão jurídica: aspectos da

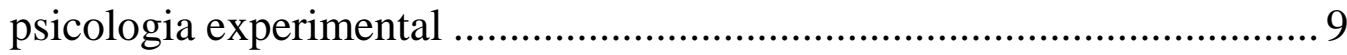

1.2. Fundamentação das decisões: o papel das citações e das referências

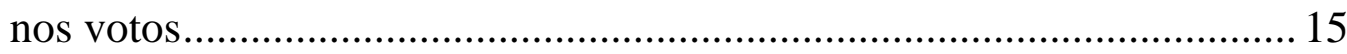

Capítulo 2 - Julgamento e deliberação no STF ........................................ 23

2.1. Ideal de corte deliberativa ........................................................ 23

2.2. Ausência de deliberação nos julgamentos do STF ........................... 25

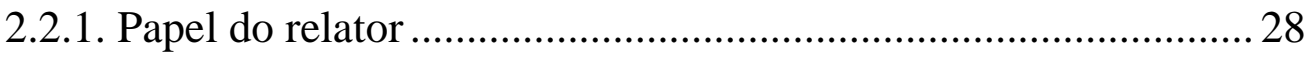

2.2.2. Demais Ministros: a manifestação sem declaração de voto, o voto pronto e suas repercussões ........................................................... 34

Capítulo 3 - Redação e aplicação dos precedentes do STF .................. 42

3.1. Dispersão de fundamentos: problemas quanto à identificação da ratio

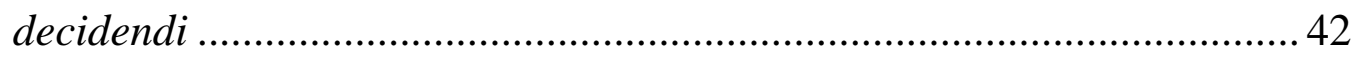

3.2. Deliberação quanto à(s) tese(s) da decisão: uma proposta em

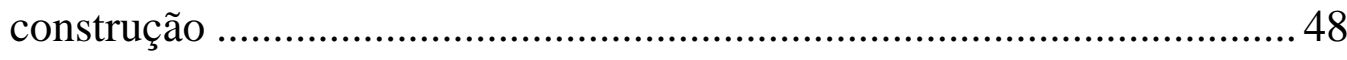

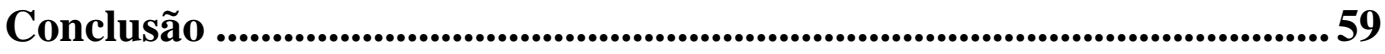

Referências bibliográficas............................................................................. 63 


\section{Lista de abreviações}

AC - Ação Cautelar

ADC - Ação Declaratória de Constitucionalidade

ADI - Ação Direta de Inconstitucionalidade

ADPF - Arguição de Descumprimento de Preceito Fundamental

AP - Ação Penal

ARE - Agravo em Recurso Extraordinário

Art. - Artigo

CNJ - Conselho Nacional de Justiça

CPC - Código de Processo Civil

CRFB - Constituição da República Federativa do Brasil de 1988

DJE - Diário de Justiça Eletrônico

HC - Habeas Corpus

Rcl - Reclamação

RE - Recurso Extraordinário

RISTF- Regimento Interno do Supremo Tribunal Federal

STF - Supremo Tribunal Federal 


\section{Introdução}

Nas últimas décadas, observou-se uma enorme ampliação da importância do papel do Supremo Tribunal Federal na sociedade brasileira. Decisões que antes se restringiam ao âmbito jurídico se alastraram por diversos espaços sociais, mobilizando a opinião pública nas mais variadas direções. À medida que a atuação do STF ganhou maior projeção em meio à população, aumentou-se o número de estudos acerca do processo decisório e deliberativo da Corte Suprema do país. Logo se intensificaram as críticas voltadas aos longos julgamentos; às manifestações cada vez mais extensas, assemelhando-se a uma verdadeira tese doutrinária; a falta de diálogo entre os votos, entre muitos outros fatores.

Como uma corte colegiada e, principalmente, uma corte constitucional dotada de competência para declarar leis inconstitucionais, a legitimidade das decisões do STF advém, dentre outros fatores, da deliberação que deve obrigatoriamente permear o seu processo decisório ${ }^{1}$. Mais do que um esforço de interação entre os membros que compõem determinado órgão, a deliberação envolve uma série de exigências que devem ser observadas tanto interna quanto externamente ao Tribunal, desde o momento em que é provocado para se manifestar sobre uma matéria específica até a conclusão do processo, com a publicação oficial da decisão ${ }^{2}$.

Em um contexto de recente solidificação de um sistema de precedentes com força vinculante pelo Código de Processo Civil de 2015, que determinou a obrigatoriedade de juízes e tribunais observarem determinadas decisões do STF, aumentou-se a importância de se verificar como os seus precedentes são formados e redigidos, visto que esse processo pode repercutir diretamente na aplicação dessas decisões por todos os

\footnotetext{
1 SILVA, Virgílio Afonso da. Deciding Without Deliberating. International Journal of Constitutional Law, Oxford University Press, v. 11, 2013, pp. 559-560.

${ }^{2}$ MENDES, Conrado Hübner. O Projeto de uma Corte Deliberativa. In: VOJVODIC, Adriana (Org.); PINTO, Henrique Motta (Org.); GORZONI, Paula (Org.); SOUZA, Rodrigo Pagani de (Org.). Jurisdição Constitucional no Brasil. São Paulo: Malheiros Editores, 2012, p. 60.
} 
operadores do direito - não só juristas, como também a administração pública e a sociedade em geral. Afinal, a aplicação de um precedente depende precipuamente da identificação da ratio decidendi - isto é, das razões de decidir do colegiado -, o que nem sempre é possível, dada a falta de um debate franco na maioria dos julgamentos do STF.

Além de analisar a dinâmica do STF como órgão colegiado, deve-se levar em consideração a postura dos seus próprios membros. É por esse motivo que muitos estudos não se detêm apenas nas decisões colegiadas, mas abordam também o perfil decisório de cada um dos componentes do STF, que, por sua vez, adquirem individualmente mais espaço na comunidade jurídica e na sociedade em geral. Com efeito, é inegável o individualismo cada vez mais presente nas posturas de cada um dos Ministros do Supremo, tendo originado alcunhas como "tribunal de solistas", "Onze ilhas"4 e "Onze Supremos" . Esse caráter individualista se reflete tanto internamente - seja nos momentos de interação no âmbito do colegiado, seja nas possibilidades legais e regimentais de atuação monocrática por parte do magistrado - quanto fora do âmbito do Tribunal, por meio principalmente da mídia ${ }^{6}$.

A presente monografia, portanto, visa a estudar o processo deliberativo no STF desde o início, a fim de identificar os motivos pelos quais não é possível caracterizá-lo, atualmente, como uma corte deliberativa, tendo como base estudos recentes sobre o tema e decisões do próprio Supremo. Considerando a impossibilidade de se esgotar a matéria, fez-se um recorte dentro de dois campos. O primeiro se refere a uma análise mais individual, deixando de lado o estudo da atuação monocrática dos

\footnotetext{
${ }^{3}$ Ibid. p. 73

${ }^{4}$ Id., Onze ilhas. Folha de S. Paulo, Tendências e Debates, 01 fev. 2010. Disponível em https://bit.ly/2GwPviF. Acesso em 22 mai. 2018.

${ }_{5}^{5}$ FALCÃO, Joaquim; ARGUELHES, Diego Werneck. Onze Supremos: todos contra o plenário. In: FALCÃO, Joaquim (Org.); ARGUELHES, Diego Werneck (Org.); FREIRE, Felipe Recondo. (Org.). Onze Supremos: O Supremo em 2016. Rio de Janeiro: Letramento, pp. 20-28, 2017.

${ }^{6}$ Veja-se, a título ilustrativo, a análise de Diego Werneck Arguelhes sobre a postura do Ministro Marco Aurélio na mídia (ARGUELHES, Diego Werneck. Afinal, ministro do Supremo é magistrado?. JOTA, 15 mar. 2016. Disponível em https://bit.ly/2KPvmoY. Acesso em 22 mai. 2018).
} 
relatores fora do âmbito das Turmas e do Pleno para focar na tomada de decisão pelos Ministros, que, posteriormente, decidirão de forma colegiada. Nesse caso, é preciso levar em consideração o fato de que os Ministros do STF são juízes como quaisquer outros, revelando-se úteis os estudos voltados à teoria da adjudicação, que investiga como os magistrados decidem. Assim, no Capítulo 1, serão utilizados instrumentos da Teoria do Direito a fim de verificar quais são os fatores que podem influenciar na tomada de decisão de um indivíduo na qualidade de Ministro, para, então, constatar como essa decisão tomada será estruturada e fundamentada.

O segundo campo de investigação é relativo à interação dos Ministros como membros de uma colegialidade para formar uma decisão, o que será desenvolvido em dois capítulos. No Capítulo 2, com base no projeto de corte deliberativa desenhado por Conrado Hübner Mendes, será tecida uma análise das práticas do STF tanto na fase anterior ao julgamento - denominada fase pré-decisional - quanto na etapa do julgamento propriamente dito - a fase decisional. No tocante à fase decisional, o estudo será dividido em duas partes, voltadas ao exame das figuras $(i)$ do relator e (ii) dos demais Ministros durante as sessões. Já o Capítulo 3 terá como foco a terceira e última etapa, a fase pós-decisional, referente à redação final dos acórdãos, notadamente com relação ao fenômeno da dispersão de fundamentos. Conforme será exposto, esse fenômeno, que resulta da ausência de diálogo efetivo entre as manifestações dos magistrados, tem como efeito direto a dificuldade de se apontar a ratio decidendi da decisão tomada, dificultando a aplicação dos precedentes formados.

Diante disso, serão apresentadas sugestões para melhorar o processo decisório colegiado, com o intuito de construir decisões mais coerentes, cuja ratio decidendi seja facilmente reconhecida. No entanto, adianta-se desde já que, enquanto os Ministros do STF não assumirem um compromisso perante a instituição e cooperarem entre si durante os julgamentos, o Tribunal não poderá ser considerado uma corte efetivamente deliberativa. 


\section{Capítulo 1 - Tomada de decisão e fundamentação dos votos pelos Ministros}

\subsection{Influência das intuições na tomada de decisão jurídica: aspectos da psicologia experimental}

Estudos mais recentes da Teoria do Direito voltados especificamente à teoria normativa da adjudicação - isto é, como decidem os juízes - têm se valido cada vez mais de outros campos do conhecimento, tais como a psicologia experimental e a economia comportamental, a fim de analisar o processo de tomada de decisão jurídica.

Apesar dos clássicos princípios jurídicos norteadores da atividade jurisdicional, como a imparcialidade e a livre convicção, não há como excluir o fato de que juízes são seres humanos como quaisquer outros e não estão imunes às influências psicológicas ou do ambiente em que se inserem. Afirmar que um juiz ou um Ministro decide única e exclusivamente com base em aspectos jurídicos revela-se como algo utópico e desprendido da realidade.

Já no século XX os realistas jurídicos norte-americanos apontavam a ingenuidade de se pensar que o julgador se valeria apenas dos elementos fático-jurídicos constantes do processo judicial para formar o seu convencimento. Os realistas revelam verdadeiro ceticismo quanto a isso ao defenderem a ideia de que o magistrado, em um primeiro momento, tomaria sua decisão com base em elementos outros, fora do âmbito jurídico, para, em um segundo momento, encontrar a roupagem jurídica de sua fundamentação ${ }^{7}$.

\footnotetext{
7 "Influenciados pelo naturalismo filosófico, os realistas afirmavam que, ao decidirem os casos concretos, os juízes respondem primariamente ao estímulo dos fatos apresentados, não importando se esses fatos têm ou não têm importância jurídica" (BRANDO, Marcelo Santini. Como decidem os juizes? Uma investigação da teoria realista da decisão judicial a partir das contribuições das ciências cognitivas e da psicologia moral. Rio de Janeiro, 2013. Dissertação (Mestrado em Direito). Departamento de Direito da PUC-Rio, p. 22).
} 
Independentemente das críticas direcionadas a essa teoria, alguns autores reconhecem a sua importância para a compreensão do processo de tomada de decisão, por estabelecer uma clara distinção entre os denominados contexto de descoberta e contexto de justificação. O primeiro se refere ao momento em que a decisão de fato é tomada e o segundo está relacionado à argumentação que será utilizada posteriormente para embasar a decisão que já existe.

Com relação ao contexto da descoberta, estudiosos do campo cognitivo identificam dois sistemas distintos que atuam no processo decisório: o intuitivo e o deliberativo. Enquanto o sistema intuitivo age de forma rápida e automática, sem que o indivíduo perceba quais fatores exercem influência no produto final - a decisão -, o deliberativo é mais racional, tendo o sujeito consciência e controle sobre os elementos que o levarão a determinada conclusão ${ }^{8}$.

Experimentos realizados por psicólogos morais, contudo, revelam que a maior parte das decisões que envolvem aspectos morais são tomadas por meio do sistema intuitivo, sendo o segundo sistema utilizado apenas para fins de justificação do que já foi decidido9 ${ }^{9}$ Tais intuições, que influenciarão diretamente a maior parte das decisões, podem ser fruto de um sentimento ou de uma sensação provenientes de aspectos intrínsecos ou extrínsecos ao indivíduo - fatores estes que podem ou não ser completamente alheios à questão que é colocada diante de $\mathrm{si}^{10}$. Esses fatores funcionam como atalhos ou heurísticas, que são "mecanismos não

\footnotetext{
${ }^{8}$ HAIDT, Jonathan. The Emotional Dog and Its Rational Tail: A Social Intuitionist Approach to Moral Judgment. Psychological review, vol. 108, n. 4, pp. 814-834, 2001, pp. 817-818.

9 "Now we know (again) that most of cognition occurs automatically and outside of consciousness (Bargh \& Chartrand, 1999) and that people cannot tell us how they really reached a judgment (...). The time may be right, therefore, to take another look at Hume's perverse thesis: that moral emotions and intuitions drive moral reasoning, just as surely as a dog wags its tail” (Ibid. p. 830).

${ }^{10} \mathrm{Um}$ dos experimentos do psicólogo moral Jonathan Haidt abordava a visão das pessoas acerca do incesto, o que, segundo o pesquisador, é uma situação que por si só causa a sensação de nojo em muitas pessoas - sensação esta que fará o indivíduo, intuitivamente, concluir pela imoralidade do ato. Já outros experimentos eram conduzidos com variações no ambiente em que a pessoa devia tomar a decisão; ora o ambiente era limpo e claro, ora se encontrava completamente sujo e desorganizado. De um mesmo caso, portanto, chegava-se a conclusões diferentes em razão de um fator completamente estranho aos elementos do caso em si. (STRUCHINER, Noel; SHECAIRA, Fábio P. Teoria da Argumentação Jurídica. Rio de Janeiro: Contraponto / Editora PUC-Rio, 2016, pp. 165-166).
} 
conscientes produzidos pelo sistema 1 [sistema intuitivo] na produção de intuições responsáveis, do ponto de vista causal, pela decisão"

As heurísticas são ignoradas pelos conscientes dos indivíduos e também dos juízes e, por serem desconhecidas, tornam-se difíceis de serem controladas. Desse modo, o sistema deliberativo, na maioria das vezes, adquire, nas palavras de Jonathan Haidt, a mera função de "advogado" do sistema intuitivo ${ }^{12}$. Isto é, o processo racional e consciente se dará no âmbito do contexto da justificação, para amparar uma decisão tomada automaticamente com base em elementos psicológicos.

Experimentos semelhantes foram aplicados a juízes, que se deparam muitas vezes com casos que extrapolam o campo da ciência jurídica, abarcando problemas ligados ao campo moral. Noel Struchiner e Fábio Shecaira, ao analisarem tais experimentos, apontam que os resultados revelam a utilização de heurísticas que não guardam qualquer relação direta com o processo a ser julgado. Exemplo disso, mencionado pelos autores, refere-se ao "efeito da atratividade física", pelo qual os indivíduos apresentam maior propensão a achar que alguém bonito é também uma pessoa boa. Assim, os julgadores, ao se depararem com um réu "bonito", tenderão a agir de forma mais benevolente ${ }^{13}$.

Nenhum desses atalhos, por óbvio, constará da fundamentação da decisão. E, muitas vezes, o próprio magistrado, ao reler os argumentos utilizados, pode se convencer de que tomou a decisão mais justa em razão de um pensamento lógico e racional. A questão da fundamentação jurídica das decisões será abordada de forma mais detalhada na seção subsequente; o que se pretende aqui é questionar se a decisão jurídica tomada por um Ministro do STF, na qualidade de juiz, baseia-se em um processo racional, lógico e consciente ou se, pelo contrário, tal decisão é alcançada por meio de heurísticas ignoradas até mesmo por si próprio.

\footnotetext{
${ }^{11}$ Ibid. p. 169.

${ }^{12}$ HAIDT, Jonathan. Op. cit., p. 820.

${ }^{13}$ STRUCHINER, Noel; SHECAIRA, Fábio P. Op. Cit., pp. 171-174.
} 
Tomando-se por base os resultados dos experimentos nos campos tanto da psicologia moral quanto da teoria da adjudicação normativa, não seria absurdo afirmar que, em uma grande parte dos casos, principalmente naqueles que englobam discussões mais sensíveis moralmente, as decisões jurídicas são tomadas de forma automática, por meio do sistema intuitivo, sem envolver qualquer reflexão jurídica ${ }^{14}$.

Por ausência de análises empíricas, não há como apontar quais seriam os atalhos, ou heurísticas, utilizados especificamente pelos Ministros do STF. E muito provavelmente semelhante análise, se realizada, não seria capaz de captar efetivamente esses dados, até porque podem existir heurísticas alheias a qualquer elemento do processo em si, como, por exemplo, questões políticas e ideológicas ${ }^{15}$.

Observando-se, todavia, o grau de relevância e de impacto na sociedade de muitas questões levadas à Corte Suprema, já é possível imaginar o amplo espectro de atalhos oferecidos pelos próprios interesses envolvidos no caso e com o potencial de influenciar a decisão dos Ministros. No âmbito do STF, são inúmeros os exemplos de casos que não se atêm ao direito, abrangendo questões morais, políticas, sociais, culturais: interrupção de gravidez de fetos anencefálicos (ADPF 54), pesquisa com células-tronco embrionárias (ADI 3.510), mensalão (AP 470), rito do processo de impeachment (ADPF 378), afastamento de parlamentares em decorrência da Operação Lava-Jato (AC 4.070 e AC 4.327), financiamento de campanha eleitoral por pessoas jurídicas (ADI 4.650), união homoafetiva

\footnotetext{
${ }^{14}$ Ibid. p. 168.

${ }^{15}$ Diego Werneck Arguelhes e Leandro Ribeiro, por exemplo, ao verificarem os casos em que houve maior divergência entre os Ministros do STF, destacam que "[o] Supremo parece se dividir mais em função de conjunturas, do contexto, e não de grandes temas constitucionais. Divide-se em função do cenário imediato da decisão e de suas implicações" (ARGUELHES, Diego Werneck; RIBEIRO, Leandro Molhano. Quando a unanimidade não esclarece. Valor Econômico, Rio de Janeiro, 22 jun. 2012). Fábio Carvalho Leite e Ivar Allan Rodriguez Hannikainen, por meio de estudo acerca de decisões envolvendo liberdade de expressão, observaram que casos semelhantes encontraram soluções diversas, sendo ambas juridicamente válidas. Sendo assim, pontuam que, se "há argumentos para os dois lados, alguns fatores que não têm relevância jurídica podem afetar a decisão do julgador", tais como a inclinação política (LEITE, Fábio Carvalho; HANNIKAINEN, Ivar Allan Rodriguez. $O$ uso de experimentos na pesquisa jurídica: experiências com a liberdade de expressão. Rio de Janeiro: 2018, no prelo).
} 
(ADI 4.277 e ADPF 132), reserva de vaga para negros em concursos públicos (ADC 41), vaquejada (ADI 4.983), entre outros.

Todos esses casos, além de envolverem aspectos sensíveis - o que já implica uma maior chance de as decisões serem tomadas sem qualquer correlação jurídica -, mobilizaram diversos grupos com interesses significativamente diferentes, aumentando, assim, a intensidade da pressão e a atenção sobre os Ministros e, consequentemente, a possibilidade de atuação do sistema intuitivo.

A influência de elementos outros além do raciocínio jurídico é, inclusive, expressamente admitida por alguns Ministros. O Ministro Marco Aurélio, por exemplo, em homenagem por ocasião de seus vinte anos como Ministro da Corte, asseverou: "Idealizo para o caso concreto a solução mais justa e posteriormente vou ao arcabouço normativo, vou à dogmática buscar o apoio" "16. O Ministro Luiz Fux, ao proferir seu voto no julgamento da ADPF 54, afirmou:

\begin{abstract}
"Hoje de manhã, acordei e agradeci a Deus por poder contribuir com a humanidade por meio de uma decisão que pode conjurar tristezas, angústias, dores, aflições e, ao mesmo tempo, pedi a Deus que a razão e a paixão me acompanhassem no exercício desse mais alto apostolado que um ser humano pode se dedicar nesse mundo de Deus: a magistratura." 17
\end{abstract}

$\mathrm{Na}$ mesma ocasião, a Ministra Rosa Weber reconheceu todos os fatores não jurídicos envolvidos na questão:

\begin{abstract}
"O tema é de uma delicadeza ímpar. E o é porque perpassa pelas nossas convicções e crenças - ou descrenças - mais profundas, e nos remete de alguma forma à questão básica existencial que nos angustia e acompanha neste voo no tempo que somos desde que nascemos (...). É isso, o olhar de cada um de nós, com nossas circunstâncias, nossos medos e nossas idiossincrasias, nossas crenças e convicções, de ordem religiosa, moral, filosófica, científica, social e cultural, que explica, em uma sociedade plural, as visões antagônicas e as defesas apaixonadas que o tema tem suscitado no seio da sociedade." 18
\end{abstract}

\footnotetext{
${ }^{16}$ S.N. Marco Aurélio vê sua homenagem como "estímulo", Revista Consultor Jurídico, 06 jul. 2010. Disponível em https://bit.ly/2GJTgzM. Acesso em 22 mai. 2018.

${ }^{17}$ STF, ADPF 54, Rel. Ministro Marco Aurélio, Brasília, 12 abr. 2012, pp. 154-155.

${ }^{18}$ Ibid. pp. 92-93.
} 
Seria ilusório exigir que um juiz formasse seu convencimento apenas com base em fundamentos fáticos e jurídicos, principalmente quando se está diante de um caso que envolve muitos outros problemas. Aliás, considerando que o direito não pode se distanciar da sociedade em que se insere, é necessário ponderar os diversos elementos em jogo. Essa ponderação ${ }^{19}$, inclusive, deverá ser incluída na própria fundamentação como percurso de um raciocínio lógico.

No entanto, a partir do momento em que o sistema intuitivo age e leva um Ministro a tomar determinada decisão de forma automática por meio de algum tipo de heurística, até que ponto essa decisão não racional será definitiva? Teria o julgador a capacidade de alterar a sua decisão pela atuação do sistema deliberativo ${ }^{20}$ ? Ou buscará apenas argumentos que embasem a conclusão alcançada automaticamente? E mais: estaria ele aberto à possibilidade de mudar de posicionamento durante a deliberação colegiada?

Juízes, Desembargadores e Ministros não estão imunes à ação do sistema intuitivo, assim como qualquer ser humano. O primeiro passo, portanto, seria que cada um dos magistrados tivesse consciência da possibilidade de tomar decisões com base em heurísticas, para, em seguida, poder avaliar criticamente, por meio do sistema deliberativo, a conclusão alcançada de forma intuitiva. Afinal, o mero fato de ser togado não outorga ao julgador, ainda que o mesmo preencha uma das onze cadeiras do Tribunal Supremo do país, qualquer tipo de poder especial que confira caráter de justiça a todas as suas intuições.

${ }^{19} \mathrm{O}$ termo ponderação, aqui, é utilizado no sentido comum e mais abrangente, sem guardar relação com o significado técnico conferido pelos autores ao estudarem os métodos de interpretação constitucional.

${ }^{20}$ No âmbito da psicologia moral experimental, pode acontecer de os indivíduos em análise serem chamados a oferecer razões para justificar a sua decisão moral e, por vezes, todas as razões apresentadas são logo refutadas por elementos do caso concreto que lhes é posto, até que se chegue ao ponto em que não há mais nenhum motivo racional para manter aquela decisão. Isso é chamado de estupefação moral, o que, todavia, nem sempre é suficiente para que o indivíduo mude a sua própria opinião. (HAIDT, Jonathan; BJORKLUND, Fredrik. Social Intuitionists Answer Six Questions About Moral Psychology. In: W. Sinnott-Armstrong (Ed.). Moral psychology. Vol. 2: The cognitive science of morality. Cambridge, MA: MIT Press, 2006, p. 15). 
De todo modo, nada disso será externado, por se tratar de um processo psicológico interno, muitas vezes desconhecido pelo próprio magistrado. O que será avaliado no mundo jurídico será a atuação do juiz no âmbito do contexto da justificação, isto é, a fundamentação de sua decisão - objeto de análise da próxima seção.

\subsection{Fundamentação das decisões: o papel das citações e das referências nos votos}

Uma vez tomada a decisão, seja pelo sistema intuitivo, seja pelo sistema deliberativo, é dever de todo magistrado fundamentá-la, nos termos do art. 93, inciso IX, da Constituição Federal. Trata-se de atuação do juiz no âmbito do contexto da justificação, que requer um raciocínio lógico, racional e com amparo jurídico, a fim de que seja válida. Assim, mesmo que uma decisão tenha sido diretamente influenciada por determinada intuição, para o mundo exterior o racional deve prevalecer, sendo que incidirão como forma de controle todos os princípios da atividade jurisdicional - que, no ordenamento brasileiro, são dotados de status constitucional.

Para embasar suas decisões e cumprir o mandamento constitucional, os Ministros utilizam, além das leis aplicáveis ao caso concreto, os mais variados artifícios: legislação estrangeira e internacional; doutrina nacional, estrangeira e internacional; julgados dos Tribunais pátrios, de Tribunais Constitucionais de outros países e de Cortes Regionais ou Internacionais; precedentes do próprio STF; decisões monocráticas por eles proferidas, ainda que não tenham sido confirmadas pelo colegiado; manifestações das partes, da Advocacia-Geral da União, da Procuradoria-Geral da República ou de instituições que tiverem atuado como amici curiae; pareceres técnicos de órgãos e institutos variados; literatura, músicas, filmes, teatro e até mesmo ditados populares. 
Muito embora todos esses instrumentos sejam amplamente utilizados nos votos, rápidas leituras dos acórdãos podem levar ao questionamento quanto ao verdadeiro papel das múltiplas citações e referências legislativas, doutrinárias, literárias, profissionais e jurisprudenciais. Carlos Ari Sundfeld e Rodrigo Pagani de Souza, em 2011, conduziram uma pesquisa ${ }^{21}$ para traçar o perfil de cada um dos Ministros no período de 21.06.2006 a 10.01.2010, em que analisaram os votos constantes de 267 acórdãos de mérito em ações de controle concentrado (ADI, ADC e ADPF) julgadas pelo Pleno do STF.

Um dos aspectos estudados foi justamente a utilização das citações, abordando-se as seguintes questões: (i) o tipo de citação mais recorrente nas manifestações de cada um dos Ministros e (ii) se costumam concordar ou discordar do conteúdo das citações inseridas nos votos. Com relação ao segundo ponto, os dados ${ }^{22}$ revelaram que, na grande maioria dos casos principalmente quando se faz referência a pareceres, manifestações realizadas em audiências públicas ou literatura -, as citações são incluídas para corroborar a posição defendida no voto. Quanto aos precedentes, também se observou que, em $94 \%$ dos casos, a referência é feita para endossar os próprios argumentos ${ }^{23}$.

Na realidade, a utilização majoritária de citações favoráveis à própria tese é prática recorrente em todo o Judiciário brasileiro, não sendo exclusiva da Suprema Corte, conforme observaram os próprios autores. Entretanto, ressaltaram que as divergências podem surgir pelo sopesamento das posições defendidas pelas partes do processo, sem que haja, portanto,

\footnotetext{
${ }^{21}$ SUNDFELD, Carlos Ari; SOUZA, Rodrigo Pagani de. Accountability e Jurisprudência do STF: Estudo Empírico de Variáveis Institucionais e Etrutura das Decisões. In: VOJVODIC, Adriana (Org.); PINTO, Henrique Motta (Org.); GORZONI, Paula (Org.); SOUZA, Rodrigo Pagani de (Org.). Jurisdição Constitucional no Brasil. São Paulo: Malheiros Editores, 2012, pp. 75-116.

22 "Consideradas apenas as citações de fontes desprovidas de efeitos normativos - ou seja, de literatura, de pareceres e de manifestações feitas em audiências públicas -, observou-se que o STF as faz geralmente para concordar com o posicionamento ou o argumento citado. Nesse sentido, apurou-se que, do total de 1.123 citações de literatura mapeadas, cerca de 3\% apenas foram acompanhadas de discordância; das 189 citações de pareceres mapeadas, cerca de $13 \%$ foram acompanhadas de discordância; e das 21 citações de manifestações em audiência pública identificadas, 5 delas, ou 23\% do total, foram acompanhadas de discordância” (Ibid. pp. 88-89).

${ }^{23}$ Ibid. p. 89.
} 
efetiva necessidade de buscar fontes externas divergentes do ponto de vista apresentado pelo Ministro em seu voto ${ }^{24}$.

A fim de verificar se tais dados se mantinham ainda hoje, analisei as citações e referências ${ }^{25}$ de seis acórdãos de mérito entre os anos de 2015 e 2017. Para tanto, selecionei casos que provocaram maior repercussão dentro e fora do mundo jurídico, de diferentes ramos do direito ${ }^{26}$. Contabilizei os dados em cinco categorias, sendo que todas abrangiam conteúdo nacional, estrangeiro e internacional. São elas: (i) doutrina; (ii) legislação; (iii) jurisprudência; (iv) manifestações das partes, da Advocacia-Geral da União, da Procuradoria-Geral da República e de amici curiae e (v) pareceres de órgãos e institutos técnicos, literatura e manifestações outras. Além disso, computei apenas as citações e referências incluídas nos votos propriamente ditos, nas suas antecipações e nos debates travados durante a sessão, excluindo o relatório do Ministro Relator e eventuais relatórios inseridos nos demais votos.

\footnotetext{
24 "A constatação desse perfil argumentativo do STF, de pouco diálogo com manifestação divergentes, todavia, deve ser matizada. Em primeiro lugar porque o diálogo com a divergência pode realizar-se não apenas com manifestações de fontes externas às partes (colhidas pelo ministro para citação), mas também é realizado com os pontos de vista divergentes das próprias partes em litígio. É possível, então, que o STF dialogue, sim, com a divergência, embora não o faça sempre com a oriunda de fontes externas às partes em litígio (ou seja, com a divergência encontrada na literatura, em pareceres, em manifestações em audiências públicas e nos precedentes do próprio Supremo). Em segundo lugar, é necessário considerar que a citação de posicionamentos divergentes não parece ser usual na própria tradição jurídica brasileira (não apenas no STF, portanto). Se a tradição é realmente de pouco diálogo com fontes para divergir, então, a eventual crítica ao perfil constatado não caberá apenas ao STF, mas à própria tradição em que está inserido" (Ibid. p. 90; grifos no original).

${ }^{25}$ Foram consideradas como citações e referências as transcrições, as paráfrases e as menções a algum autor, estudo, manifestação, dispositivo ou julgado, na esteira das definições de citação ("ato de citar"), citar ("transcrever, referir ou mencionar como autoridade ou exemplo ou em apoio do que se afirma") e referência ("ação de referir, de reportar-se a um texto, a um documento, a uma autoridade"; "sinal ou indicação que remete o leitor a outra fonte de informação"), todas retiradas do Dicionário Houaiss da Língua Portuguesa (HOUAISS, Antônio; VILLAR, Mauro de Salles; FRANCO, Francisco Manoel de Mello. Dicionário Houaiss da Língua Portuguesa. $1^{\text {a }}$ ed. Rio de Janeiro: Objetiva, 2001; p. 732 e p. 2411).

${ }^{26}$ Os casos analisados foram os seguintes: no direito civil, as biografias não autorizadas (ADI 4.815, julgada em 10.06.2015); no direito penal, a execução da pena depois da condenação em segunda instância (HC 126.292, julgado em 17.02.2016); nos direitos sociais, a vaquejada (ADI 4.983, julgada em 06.10.2016); no direito administrativo, os descontos por dias não trabalhados durante a greve de servidores públicos (RE 693.456, julgado em 27.10.2016); no direito tributário, a imunidade tributária de livros eletrônicos (RE 330.817, julgado em 08.03.2017); e, no direito administrativo, a reserva de vagas para negros em concursos públicos (ADC 41, julgada em 08.06.2017).
} 
Mesmo sem a pretensão de se fazer um levantamento quantitativamente significativo, os poucos votos mais recentes analisados evidenciaram que a tendência observada por Sundfeld e Souza em 2011, ao menos nos casos de grande impacto social e com maior repercussão midiática, foi mantida pela atual composição do STF. Isto é, as citações e as referências são majoritariamente utilizadas pelos Ministros para corroborar seus próprios argumentos, visto que, do total de 1.178 citações e referências incluídas nos votos, 1.067 foram utilizadas para corroborar a posição ali defendida - o que corresponde a $91 \%$ do total $^{27}$.

Por mais que Sundfeld e Souza tenham mencionado a possibilidade de a divergência advir das manifestações das partes em litígio, a amostra que analisei demonstrou que são poucos os votos que debatem de forma mais densa os argumentos contrários. Não raramente, o Ministro se limita a expor em uma ou duas frases qual a tese contrária, sem efetivamente testar a sua plausibilidade, e não são poucos os votos que sequer mencionam a divergência existente. Dos 58 votos analisados, apenas 23, isto é, $40 \%$ do total, detiveram-se com maior cuidado sobre a posição contrária à sua. Em 25 votos, não houve diálogo algum com os argumentos contrários, enquanto os demais 10 lhes dedicaram pouquíssimas palavras.

Observou-se, pois, que toda a estrutura da fundamentação é construída para amparar da forma mais enfática possível a sua própria posição. Em outras palavras, depois que os Ministros e os juízes como um todo tomam uma decisão em seu foro íntimo - e, conforme já exposto, a probabilidade de essa decisão ter sido engatilhada por uma intuição é bastante grande -, buscarão todo o material disponível para oferecer amplo respaldo àquela conclusão, muitas vezes ignorando ou minimizando, ao menos pelo que transmitem externamente, opiniões contrárias e que

\footnotetext{
${ }^{27}$ Os resultados por categoria foram os seguintes: (i) das 298 citações de doutrina, apenas 3 eram contrárias à posição do Ministro, ou seja, 1\%; (ii) das 300 citações de legislação, 253, ou 84\%, eram favoráveis à tese defendida no voto; (iii) das 376 citações de jurisprudência, 337, isto é, $90 \%$ do total, foram usadas para embasar a própria visão; (iv) das 60 citações de manifestações durante o curso do processo, apenas $9(15 \%$ do total) eram contrárias à própria posição; e $(v)$ das 144 citações de pareceres de órgãos técnicos, literatura, dados estatísticos e manifestações outras, 131 (91\% do total) foram utilizadas para corroborar o entendimento do Ministro.
} 
poderiam levar a um caminho oposto. Isso porque as fontes externas à lide, na esmagadora maioria das vezes, servirão apenas para reforçar o argumento defendido, sem que outras fontes, que poderiam esclarecer os pontos divergentes levantados pelas partes, sejam sequer consideradas.

$\mathrm{Na}$ mesma linha da ideia de Haidt sobre a função do sistema deliberativo como mero advogado do sistema intuitivo, essa forma de fundamentar pronunciamentos judiciais conduz à impressão de que os juízes, e especificamente os Ministros do STF, atuam mais como advogados do que propriamente como juízes ${ }^{28}$. Afinal, advogados são aqueles que, por excelência, buscarão todo o respaldo possível para defender os interesses de seus clientes, a fim de fazer sobressair a tese favorável e derrubar a desfavorável. Dos advogados não é exigido que busquem todas as posições existentes acerca do tema, sendo perfeitamente legítimo - e necessário que adotem postura escancaradamente parcial.

O mesmo não se pode dizer dos juízes que, em tese, deveriam analisar o caso que lhes é apresentado de forma imparcial, isto é, equidistante com relação aos interesses em conflito - o que não se observa na prática, dada $(i)$ a enorme quantidade de citações favoráveis à tese que defendem e (ii) a não rara ausência de menção aos conflitos existentes. Carlos Ari Sundfeld e Rodrigo Pagani de Souza, a partir dos dados obtidos, chegaram à mesma conclusão, apresentando a seguinte reflexão:

\begin{abstract}
"Os números sugerem que as citações são inseridas nos votos para corroborar os pontos de vista defendidos pelos ministros. A fundamentação de cada voto é estruturada para persuadir a partir de manifestações no mesmo sentido, isto é, para convencer sobre o acerto da posição sustentada a partir dessas manifestações. Esse perfil de argumentação demonstrado pela Corte no período analisado - um perfil, em suma, de pouco diálogo com manifestações divergentes - pode ser comparado à maneira pela qual o advogado costuma construir sua argumentação, qual seja, sobrevalorizando citações favoráveis ao ponto de vista defendido (e às vezes desvalorizando ou até omitindo citações desfavoráveis)." ${ }^{29}$
\end{abstract}

\footnotetext{
${ }^{28}$ Interessante observar que um dos autores realistas mais conhecidos, Jerome Frank, "sustenta que a tomada de decisão judicial não difere da atividade desempenhada por um advogado: primeiro o advogado pensa em uma solução para o problema do cliente; em seguida busca na legislação e nos precedentes o material jurídico que dê suporte a essa solução" (BRANDO, Marcelo Santini. Op. cit., p. 23).

${ }^{29}$ SUNDFELD, Carlos Ari; SOUZA, Rodrigo Pagani de. Op. cit., p. 89.
} 
Diante disso, pode se tornar preocupante a postura parcial dos Ministros do STF, e dos juízes brasileiros em geral, notadamente se se considerar a grande possibilidade de a maioria de suas decisões serem impulsionadas por intuições, sobre as quais não possuem controle algum. Desse modo, argumentos contrários serão descartados não por meio de um raciocínio lógico, mas de forma automática e intuitiva - podendo acarretar, inclusive, desequilíbrio na relação processual.

Não se ignora o entendimento dos estudiosos cognitivos quanto à precisão da maioria das intuições ${ }^{30}$. Todavia, muitas vezes, não existe uma resposta certa ou errada para determinado problema jurídico. Prova disso são os votos divergentes com fundamentação igualmente válida em muitos dos casos julgados pelo $\mathrm{STF}^{31}$. Ademais, o foco da análise, aqui, é a primazia demasiada que se dá à própria opinião em detrimento dos entendimentos contrários. É claro que há casos em que a tese vencedora encontra maior assento tanto na doutrina quanto na sociedade, tornando mais tranquila a sua aceitação sem uma análise mais detida da posição contrária $^{32}$. Por outro lado, há situações extremamente controvertidas que mereceriam maior atenção com relação a todos os interesses envolvidos - o que, no entanto, nem sempre ocorre na prática ${ }^{33}$.

\footnotetext{
30 Jonathan Haidt, por exemplo, afirma: "we should instead look for the roots of human intelligence, rationality, and virtue in what the mind does best: perception, intuition, and other mental operations that are quick, effortless, and generally quite accurate" (HAIDT, Jonathan. Op. cit., p. 822).

${ }^{31}$ Cite-se como exemplo o RE 693.456 sobre a possibilidade de corte nos salários dos servidores públicos por dias não trabalhados durante uma greve. Nesse caso, os Ministros debateram longamente, já que as preocupações envolvendo o tema eram semelhantes, porém as conclusões alcançadas eram divergentes.

${ }^{32}$ No caso da imunidade tributária de livros eletrônicos (RE 330.817), em que a votação foi unânime, muito embora poucos Ministros tenham enfrentado os argumentos contrários, o resultado se alinhou à jurisprudência construída por anos pelo STF, encontrando também ampla aceitação em sede doutrinária.

${ }^{33}$ Quanto à possibilidade de execução de pena depois da condenação em segunda instância (HC 126.292), cuja votação se deu por 6 votos a 4, as críticas doutrinárias continuam, até hoje, muito fortes. Nada obstante, dos 10 votos proferidos, apenas 2 analisaram com mais cuidado a posição contrária. Em 6 votos, os argumentos opostos não foram mencionados, enquanto nos outros 2, houve abordagem mais superficial. Já no caso das biografias não autorizadas (ADI 4.815), todos os 8 Ministros que participaram do julgamento se detiveram mais longamente sobre os argumentos contrários e, muito embora houvesse ampla divergência nas demais instâncias judiciais, a votação foi unânime e o resultado encontra apoio significativo na doutrina.
} 
Não é demais ressaltar, ainda, que encontrar roupagem jurídica às próprias intuições, quando se trata de matéria constitucional especificamente no direito brasileiro, não se revela tarefa difícil, dada a textura aberta ${ }^{34}$ dos dispositivos constitucionais, que oferecem ampla gama de interpretações. E, de fato, muitos dos recentes julgamentos do STF têm demonstrado uma enorme criatividade dos Ministros, que reinventam cada vez mais as normas constitucionais por meio de todos os métodos de interpretação, conforme o que julgam ser mais adequado à conclusão a que desejam chegar. Há casos, inclusive, em que se firmou entendimento frontalmente contrário ao texto ${ }^{35}$ - que, teoricamente, deveria ser considerado como limite da atividade interpretativa.

Como exemplo, cite-se o julgamento da Reclamação 4.335, em que o relator, Ministro Gilmar Mendes, sustentou a ideia de que o art. 52, inciso X, da Constituição Federal, teria sofrido mutação constitucional. Segundo o Ministro, não haveria mais diferença entre as decisões proferidas em sede de controle concentrado e aquelas tomadas no âmbito do controle incidental. Assim, devido à teoria da transcendência dos motivos determinantes, a decisão do STF em controle incidental acerca da inconstitucionalidade de uma lei, por si só, já teria efeitos erga omnes. Consequentemente, a resolução editada pelo Senado nos termos do referido dispositivo constitucional teria como objetivo apenas publicizar a posição

\footnotetext{
${ }^{34}$ A textura aberta dos dispositivos normativos decorre da textura aberta da própria linguagem. Como as normas devem ser genéricas e abstratas, os termos utilizados nos textos normativos devem ser igualmente genéricos - o que pode implicar problemas no momento da interpretação, já que termos vagos naturalmente apresentam uma zona de penumbra, gerando dúvidas quanto ao seu significado. Assim, Struchiner aponta que "a decisão acerca da aplicação da regra num caso concreto muitas vezes recai na questão sobre o significado, ou abrangência de um termo geral classificatório na regra" (STRUCHINER, Noel. Aplicação e Consequiências da Noção de Textura Aberta da Linguagem para a Filosofia do Direito. In: I SAF-PUC, 2001, Rio de Janeiro. AnaLógos - Anais da I SAF-PUC. Rio de Janeiro: Booklink, 2001, p. 97).

${ }^{35}$ Dimitri Dimoulis, por exemplo, apresenta fortes críticas à interpretação conferida pelo Ministro Ricardo Lewandowski ao art. 52, parágrafo único, da Constituição Federal, durante o julgamento do impeachment da ex-presidente Dilma Rousseff. Segundo o autor, "ao permitir a votação das sanções em separado, o Lewandowski parece ter alterado um mandamento constitucional expresso". E vai além, afirmando que "os ministros não consideram a letra da Constituição como relevante obstáculo quando a solução que essa letra dita lhes parece disfuncional". (DIMOULIS, Dimitri. A Constituição interpretada sem regras. In: FALCÃO, Joaquim (Org.); ARGUELHES, Diego Werneck (Org.); FREIRE, Felipe Recondo. (Org.). Onze Supremos: O Supremo em 2016. Rio de Janeiro: Letramento, 2017, pp. 63-64).
} 
do Tribunal $^{36}$ - muito embora o texto estabeleça expressamente que compete ao Senado Federal "suspender a execução, no todo ou em parte, de lei declarada inconstitucional por decisão definitiva do Supremo Tribunal Federal'. Outros Ministros, por sua vez, ressaltaram a impossibilidade de acolher a tese de mutação constitucional proposta pelo relator justamente em decorrência das barreiras impostas pela interpretação literal ${ }^{37}$.

Construções de tal ordem, devido à sua originalidade e por reinventarem normas constitucionais, requerem um esforço argumentativo ainda maior por parte dos julgadores, que se veem obrigados a incluir ainda mais citações e referências a seu favor - como ocorreu no caso do voto do Ministro Gilmar Mendes na Reclamação 4.335. Todo esse processo de construção da fundamentação ocorre, ao menos nos casos com maior repercussão e de maior relevância, de forma individual, depois que o Ministro já tomou a sua decisão e busca se armar com os mais robustos argumentos para defender a sua própria tese. Nesse contexto, qual seria, afinal, a função das sessões de julgamentos das Turmas ou do Pleno do STF? É o que se verá no próximo capítulo.

\footnotetext{
${ }^{36}$ STF, Rcl 4.335, Rel. Ministro Gilmar Mendes, Brasília, 20 mar. 2014, pp. 53-55.

37 O Ministro Joaquim Barbosa arguiu "encontrar obstáculo intransponível na literalidade do artigo 52, inciso X da Constituição" (Ibid. p. 101). O Ministro Ricardo Lewandowski assim ressaltou: "se o dispositivo em questão assinala, com todas as letras, que compete ao Senado Federal a suspensão de norma declarada inconstitucional por esta Corte, assim o é, literalmente" (Ibid. p. 125). O Ministro Roberto Barroso assentou: "encontro, como limite a esse processo de mutação constitucional, a textualidade dos dispositivos constitucionais. De forma que, embora goste da ideia, acho que ela não é compatível com o Texto Constitucional, na redação do art. 52, $X$ ” (Ibid. p. 185). Na mesma esteira seguiu a Ministra Rosa Weber, que afirmou: "Entendo que a literalidade do texto - aspecto que foi muito bem destacado pelo Ministro Luís Roberto - não me permite chegar à conclusão da mutação constitucional, porque não seria uma mudança" (Ibid. p. 188).
} 


\section{Capítulo 2 - Julgamento e deliberação no STF}

\subsection{Ideal de corte deliberativa}

A legitimidade da decisão de um colegiado - principalmente quando se trata de um tribunal constitucional com atribuição para declarar a inconstitucionalidade de uma lei com efeito vinculante com relação às demais instâncias do Poder Judiciário e até mesmo à administração pública - advém, dentre outros fatores, de um processo genuinamente deliberativo que leva à tomada de decisão.

Segundo Conrado Hübner Mendes, deliberação pode ser definida como "uma forma exigente de interação no processo de tomada de decisão, por meio do qual razões de um tipo específico são trocadas na tentativa de persuadir e alcançar o consenso" "38. O autor sustenta que essa interação se dá não só entre os órgãos julgadores que compõem o colegiado, como também com as partes do processo, amici curiae e outros interlocutores, em três fases: (i) pré-decisional, (ii) decisional e (iii) pós-decisional. Uma corte idealmente deliberativa, portanto, preocupa-se com os instrumentos de interação nas três etapas.

A primeira fase - que se inicia no momento em que se provoca a corte com um novo caso - é marcada pela contestação pública, em que os interlocutores desempenham um papel tão importante quanto os julgadores. O primeiro grupo, composto por todos os interessados na matéria a ser examinada, submete os argumentos pertinentes ao colegiado em audiências públicas, manifestações escritas e sustentações orais. Já ao segundo grupo cabe ler e ouvir atentamente os argumentos que lhe são trazidos, bem como,

\footnotetext{
${ }^{38}$ MENDES, Conrado Hübner. O Projeto de uma Corte Deliberativa. In: VOJVODIC, Adriana (Org.); PINTO, Henrique Motta (Org.); GORZONI, Paula (Org.); SOUZA, Rodrigo Pagani de (Org.). Jurisdição Constitucional no Brasil. São Paulo: Malheiros Editores, 2012, p. 60.
} 
quando possível, interpelar os interlocutores para melhor elucidar eventuais pontos controvertidos ${ }^{39}$.

A etapa decisional se refere à interação colegiada com o objetivo, como o próprio nome indica, de se alcançar uma decisão. Nessa fase, a deliberação envolve um diálogo entre as razões expostas por cada juiz, não só para se chegar a um consenso, como também para originar o que Mendes denomina de "boa decisão", isto é, "permeável a um amplo espectro de argumentos expostos por variadas fontes" ${ }^{40}$. Mais do que apresentar fundamentos eruditos e convincentes, é preciso que cada juiz assimile e interaja com os argumentos apresentados tanto pelos interlocutores quanto pelos outros julgadores, a fim de se estabelecer um terreno propício para o consenso ou o menor dissenso possível.

É nessa fase em que se destaca a colegialidade, que, segundo Virgílio Afonso da Silva, envolve algumas características que serão essenciais à deliberação. São elas:

\begin{abstract}
“(i) a disposição de trabalhar como um time; (ii) a ausência de hierarquia entre juízes (pelo menos no sentido de que os argumentos de todos e quaisquer juízes têm o mesmo valor); (iii) a vontade de escutar os argumentos apresentados por outros juízes (i.e. estando aberto a ser convencido por bons argumentos de outros juízes); (iv) a cooperatividade no processo de tomada de decisão; (v) respeito mútuo entre juízes; (vi) disposição de falar, sempre que possível, não como uma soma de indivíduos mas como uma instituição." ${ }^{41}$
\end{abstract}

Por fim, a última fase consiste em uma decisão escrita deliberativa. A redação final apresentada ao mundo externo deve ser redigida com a preocupação de ser acessível à população em geral - e não só aos profissionais do direito - e aplicável a casos futuros sem dificuldades de interpretação quanto àquilo que foi efetivamente decidido. Assim, Mendes explica que, nessa etapa, é necessário "balancear a necessidade de

\footnotetext{
39 “(...) a corte deve liderar a fase pré-decisional com uma série de propósitos em mente: coletar, tanto quanto possível, argumentos dos interlocutores; desafiar publicamente esses argumentos, de modo que os interlocutores tenham oportunidade de refiná-los ou depurá-los; e, acima de tudo, mostrar abertura aos atores que podem ter algo a acrescentar ao estoque de argumentos de cada caso" (Ibid. p. 62).

${ }^{40}$ Ibid. p. 63.

${ }^{41}$ SILVA, Virgílio Afonso da. Op. cit., pp. 562-563; tradução livre.
} 
construir uma identidade institucional com o dever de respeitar o lugar e o valor de opiniões dissidentes" $"$.

Há diversas maneiras de uma decisão ser redigida na fase pósdecisional: seriatim, apresentando-se os diversos votos separadamente; per curiam, contendo uma única decisão que compile as opiniões proferidas durante a fase anterior; ou formatos intermediários, diferenciando, por exemplo, os votos concorrentes dos dissidentes. Independentemente do modelo adotado, a decisão escrita pode se mostrar deliberativa ou não, a depender do compromisso que se tem com a instituição em si e com a decisão alcançada de forma colegiada, de modo a transparecer um efetivo diálogo entre as várias posições. Em outras palavras, caso a escrita final não transpareça uma comunicação entre as opiniões sustentadas durante a interação colegiada, nem represente a decisão alcançada pelo colegiado em si, isso significará a ausência de deliberação na fase pós-decisional.

A fim de que uma corte seja considerada verdadeiramente deliberativa, portanto, é imprescindível obedecer aos padrões exigentes relativos a cada uma das etapas do processo de deliberação ${ }^{43}$. Com base nisso, cumpre agora analisar como se dão os julgamentos no STF, para verificar os motivos pelos quais o Tribunal Supremo brasileiro não pode ser considerado uma corte deliberativa.

\subsection{Ausência de deliberação nos julgamentos do STF}

Analisando-se a rotina do STF à luz do projeto de corte deliberativa exposto por Conrado Hübner Mendes, não é difícil perceber as inúmeras falhas em todas as etapas do seu processo de tomada de decisão, que impedem a caracterização do Tribunal como uma verdadeira corte deliberativa.

\footnotetext{
${ }^{42}$ MENDES, Conrado Hübner. Op. cit., p. 65.

43 "Uma corte genuinamente deliberativa, de maneira curta e direta, é aquela que maximiza o raio de argumentos dos interlocutores ao promover contestação pública na fase pré-decisional; que estimula os juízes numa prática sincera de interação colegiada na fase decisional; e que redige uma decisão deliberativa na fase pós-decisional” (Ibid. p. 60).
} 
$\mathrm{Na}$ fase pré-decisional, muito embora tenha havido, nos últimos anos, maior abertura para instituições atuarem como amici curiae, a interação entre interlocutores e Ministros não se mostra ideal. Mendes, por exemplo, ressalta que a maior utilização do instituto do amicus curiae não repercutiu efetivamente nas fases decisional e pós-decisional, já que não há "interesse em escutar, e muito menos em responder (seja para concordar ou para discordar)" ${ }^{m 4}$.

Além disso, nos casos em que há designação de audiência pública teoricamente com o intuito de ampliar o espaço para o debate, não raramente, apenas o relator comparece, sendo que não existe real interação. Isso porque o relator apenas escuta, enquanto os representantes das partes e dos amici curiae se limitam a ler manifestações prontas, impossibilitando, assim, o diálogo entre os interlocutores e o Tribunal. Por mais que, posteriormente, os julgadores ausentes tenham acesso às manifestações dos interessados por escrito, não será mais possível questionar as razões expostas pelos indivíduos e instituições, seja para elucidar eventuais dúvidas, seja para apresentar um contraponto à visão defendida - atividades essas que, na prática, também não ocorrem com os Ministros que comparecem, a despeito do tempo despendido com a audiência.

Quanto à fase decisional, a dinâmica durante as sessões de julgamento será analisada nas subseções abaixo. Contudo, não há como deixar de mencionar a curiosa solução para otimizar a análise acerca da existência ou não de repercussão geral em recursos extraordinários: o plenário virtual, aberto com manifestação do relator - que, na prática, já expõe a sua posição quanto ao mérito da matéria ${ }^{45}$-, seguida dos votos dos

\footnotetext{
${ }^{44}$ Ibid. p. 71.

${ }^{45}$ Prova disso é uma simples análise das teses de repercussão geral no site do STF: ao invés de se limitarem a indicar que determina matéria preenche ou não esse requisito, fixam desde já a posição do relator quanto ao mérito, antes mesmo de saber se o quórum necessário para o reconhecimento de repercussão geral será alcançado. Como exemplos, citem-se as teses fixadas na primeira manifestação do relator no âmbito dos temas 937 e 959, oriundos, respectivamente, do ARE 999.425 e do RE 1.038.925: "Os crimes previstos na Lei $n^{\circ} 8.137 / 1990$ não violam o disposto no art. $5^{\circ}$, inc. LXVII, da Constituição da República" e "É inconstitucional a expressão 'e liberdade provisória', constante do caput do artigo 44 da Lei $n^{\circ} 11.343 / 2006^{\prime}$. Nos acórdãos relativos à análise de repercussão geral, o Ministro Marco Aurélio é o único que inclui seu próprio
} 
outros Ministros na plataforma digital, cada qual a seu tempo, sem qualquer exposição de motivos, muito menos interação entre os julgadores.

Mesmo que não se trate, em tese, de julgamento de mérito propriamente dito, é inegável a importância de averiguar se o assunto abordado é dotado ou não de repercussão geral. Afinal, essa mera análise já repercutirá de imediato em todos os outros recursos extraordinários que versarem sobre a mesma matéria: negada a existência de repercussão geral, será negado seguimento aos demais recursos, nos termos do art. 1.035, $\S 8^{\circ}$, do Código de Processo Civil ${ }^{46}$; reconhecida a repercussão geral, os recursos permanecerão suspensos até o julgamento definitivo de mérito, conforme predispõe o $\S 5^{\circ}$ do mesmo dispositivo ${ }^{47}$. Nada obstante isso, há uma flagrante ausência de deliberação nessa fase processual - dando margem, inclusive, a questionamentos sobre violações aos princípios da colegialidade $^{48}$ e da motivação das decisões judiciais.

Com relação à fase pós-decisional, a elaboração do acórdão final será objeto de estudo do capítulo seguinte. Anteriormente, é preciso analisar como se dão os julgamentos colegiados no STF, mais especificamente a postura (i) do relator e (ii) dos demais Ministros, identificando, em ambos os grupos, os motivos que levam à falta de deliberação, bem como propostas que poderiam ser adotadas com o intuito de aprimorar o processo decisório no STF.

\footnotetext{
pronunciamento, em que reitera que o plenário virtual não é o espaço adequado para se manifestar sobre o mérito do recurso extraordinário (BRASIL. Teses de Repercussão Geral. Supremo Tribunal Federal. Disponível em: https://bit.ly/2KMGT8u. Acesso em 22 mai. 2018).

${ }^{46} \mathrm{CPC} / 2015$, art. 1.035, $\S 8^{\circ}$ : "Negada a repercussão geral, o presidente ou o vice-presidente do tribunal de origem negará seguimento aos recursos extraordinários sobrestados na origem que versem sobre matéria idêntica."

${ }^{47} \mathrm{CPC} / 2015$, art. $1.035, \S 5^{\circ}$ : "Reconhecida a repercussão geral, o relator no Supremo Tribunal Federal determinará a suspensão do processamento de todos os processos pendentes, individuais ou coletivos, que versem sobre a questão e tramitem no território nacional."

48 Segundo o Ministro Marco Aurélio, por exemplo, "plenário virtual não é plenário: o sentido do colegiado é a troca de ideias, é nos completarmos mutuamente" (S.N. Ministro Marco Aurélio: "Plenário virtual não é plenário, o sentido de colegiado é a troca de ideias". Migalhas, 04 jul. 2016. Disponível em https://bit.ly/2x6VDgf. Acesso em 22 mai. 2018).
} 


\subsubsection{Papel do relator}

A despeito da descrição, em lei, das funções do relator nos processos e recursos que tramitam perante tribunais em geral, quando se trata especificamente de uma corte que também atua como guardiã da Constituição, muitas divergências surgem quanto ao verdadeiro papel que o relator exerce e, mais especificamente, quanto à função do seu voto. Por mais que seja comum ouvir dizer que o relator baliza o debate, a rotina do STF revela que a resposta não é tão simples assim.

Virgílio Afonso da Silva, ao apresentar estudo com foco na figura do relator baseado em entrevistas que performou com antigos e atuais Ministros do STF, destacou a importância de se estabelecer uma divisão entre os casos menos e mais importantes ${ }^{49}$. Segundo o autor - e isso pode ser facilmente observado na prática do Tribunal -, há uma distinção entre (i) as decisões meramente repetitivas, sem qualquer repercussão, e (ii) as decisões que envolvem maiores discussões e um grau mais elevado de engajamento por parte dos próprios julgadores ${ }^{50}$.

No primeiro caso, considerando principalmente o fato de que, na maioria das vezes, o único voto escrito será o do relator, Silva afirma que tal ministro exercerá efetivamente um papel preponderante quanto à

\footnotetext{
49 "Se o que se quer analisar é o papel do Supremo Tribunal Federal como corte constitucional, seu papel na relação entre os poderes, então não faz sentido investigar como os ministros se comportam nas decisões das dezenas de milhares de agravos de instrumento, por exemplo. O que importa é a atitude dos ministros nas decisões que fazem parte do cotidiano de todos os tribunais constitucionais, como aquelas sobre reforma política, financiamento partidário, aborto, pesquisa em células-tronco, casamento de pessoas do mesmo sexo, ações afirmativas, drogas, etc." (SILVA, Virgílio Afonso da. 'Um Voto Qualquer'? O papel do ministro relator na deliberação no Supremo Tribunal Federal. REI - Revista Estudos Institucionais: Revista da Faculdade Nacional de Direito da UFRJ, v. 1, 2015, p. 188).

${ }^{50}$ Silva não apresenta critérios metodológicos para distinguir, aprioristicamente, quais decisões integrariam o primeiro ou o segundo grupo. Não seria correto, portanto, afirmar que os casos mais importantes se referem à atuação do STF como corte constitucional, enquanto os casos menos importantes seriam aqueles em que o Tribunal atua como instância recursal. Isso porque, pelo próprio histórico das decisões emblemáticas do Supremo (como, por exemplo, o HC 82.424, também conhecido como "caso Elwanger"), percebe-se que uma decisão oriunda de um caso concreto pode ser tão importante quanto uma ação direta de inconstitucionalidade, ao passo que existem ações de controle concentrado que não apresentam repercussão nenhuma nos meios político, social e acadêmico (SILVA, Virgílio Afonso da. O relator dá voz ao STF? Uma réplica a Almeida e Bogossian. REI - Revista Estudos Institucionais: Revista da Faculdade Nacional de Direito da UFRJ, v. 2, 2016, pp. 665-666).
} 
definição das razões de decidir do colegiado ${ }^{51}$. Nessas hipóteses, assim como ocorre na grande maioria dos julgamentos colegiados dos demais tribunais do país, não raramente os outros julgadores sequer leem o relatório e acabam por seguir o voto do relator sem conhecimento do caso ou sem análise efetiva dos fundamentos levantados por esse voto ${ }^{52}$. Ou seja, apesar da frequente unanimidade, a decisão não terá sido fruto de efetiva deliberação, mas sim do juízo de um único Ministro.

No segundo grupo, relativo aos casos mais importantes, por sua vez, tem sido prática cada vez mais recorrente que os demais Ministros também levem votos prontos à sessão de julgamento, de modo que o voto do relator perde consideravelmente sua relevância. Soma-se a isso um problema citado por todos os Ministros entrevistados por Silva: o segredo com relação ao voto do relator, que, muitas vezes, só é revelado durante a sessão de julgamento ${ }^{53}$. Essa prática impede que os demais Ministros possam se debruçar sobre os fundamentos trazidos por aquele que deveria balizar o debate, prejudicando, assim, a própria deliberação durante a interação colegiada $^{54}$.

Em outras palavras, seja nos casos de menor relevância, seja naqueles de maior repercussão, pode-se questionar qual seria exatamente o debate balizado pelo voto do relator - o que se agrava se se considerar a postura dos demais Ministros, conforme será exposto na subseção seguinte.

\footnotetext{
${ }^{51}$ Ibid. p. 660.

${ }^{52}$ Id., 'Um Voto Qualquer'? O papel do ministro relator na deliberação no Supremo Tribunal Federal. REI - Revista Estudos Institucionais: Revista da Faculdade Nacional de Direito da UFRJ, v. 1, 2015, p. 189.

${ }^{53}$ Ibid. p. 193.

${ }^{54}$ A distribuição prévia do voto do relator aqui defendida se refere aos julgamentos presenciais pelos órgãos colegiados - Turmas ou Pleno -, excluindo o plenário virtual. Conforme exposto na seção 2.2 (v. nota de rodapé $n^{\circ} 45$ ), ao se manifestar pela existência ou não de repercussão geral, o relator já insere, no plenário virtual, a sua posição quanto ao mérito, antes mesmo de saber se o recurso poderá ser levado a julgamento ou não. Quando os outros Ministros se manifestam no plenário virtual, não há como saber se aderem ou não à tese referente ao mérito proposta pelo relator, gerando uma situação completamente anômala. Em outras palavras, é saudável que o relator distribua anteriormente seu voto somente antes de sessões presenciais, o que não corrobora absolutamente a prática de adiantar o próprio posicionamento quando da análise de repercussão geral.
} 
Indagados sobre a função do relator e do seu voto ${ }^{55}$, embora a maioria tenha afirmado que enxerga o relator como uma figura decisiva no processo decisório ${ }^{56}$, alguns Ministros entrevistados também reconheceram que existe uma diferença entre os casos repetitivos e as decisões mais polêmicas. Segundo um deles, nas matérias que despertam maior interesse fora do âmbito do Tribunal, o pronunciamento do relator seria "um voto qualquer"57.

Em resposta ao artigo de Silva, Danilo dos Santos Almeida e Andre Martins Bogossian rebateram a premissa de que o voto do relator, nos casos mais relevantes, não exerceria papel preponderante. Para os autores, a inclusão na parte dispositiva da grande maioria dos acórdãos da expressão "nos termos do voto do relator" indicaria, na realidade, uma postura delegacionista dos demais Ministros ${ }^{58}$. Isto é, os outros julgadores, a despeito de proferirem votos com fundamentos próprios, delegariam ao voto do relator - ou ao primeiro voto vencedor - a função de estabelecer as razões de decidir do STF como instituição ${ }^{59}$. Ainda assim, Almeida e

\footnotetext{
${ }^{55}$ Além do papel do voto em si, os autores e os Ministros entrevistados por Silva destacam outras funções do relator, como, por exemplo, o poder de agenda ao determinar quando o caso está maduro para ser levado a julgamento. Um dos Ministros, inclusive, afirmou que esse poder do relator tem influência direta na deliberação, ao abrir possibilidade de se suprimir o debate (Ibid. p. 190). Há, também, análises acerca do poder que o relator pode exercer de forma individual. Nesse sentido, v. ARGUELHES, Diego Werneck; RIBEIRO, Leandro Molhano. O Supremo Individual: mecanismos de influência direta dos Ministros sobre o processo político. Direito, Estado e Sociedade, Revista do Departamento de Direito da PUC-Rio. Rio de Janeiro, n. 46, pp. 121-155, 2015.

${ }^{56}$ SILVA, Virgílio Afonso da. Op. cit., p. 188.

${ }^{57}$ Ibid. p. 189.

${ }^{58}$ Posteriormente ao trabalho de Almeida e Bogossian, Silva publicou réplica questionando o peso conferido pelos autores à expressão "nos termos do voto do relator", notadamente nos casos que ele próprio denomina "mais importantes": "a interpretação que eles dão a essa expressão pareceme incompatível com a prática decisória recente do tribunal, ao menos nos casos mais importantes, nos quais ministros e ministras levam para a sessão de julgamento seus votos, longos e detalhados, já escritos" (Id., O relator dá voz ao STF? Uma réplica a Almeida e Bogossian. REI - Revista Estudos Institucionais: Revista da Faculdade Nacional de Direito da UFRJ, v. 2, 2016 p. 667).

59 "Se a hipótese delegacionista for confirmada, então o voto do relator não pode ser considerado 'um voto qualquer'. De certa forma, ele cumpre exatamente o papel que Silva sustenta ser do relator em tribunais de outros países e que não poderia cumprir no STF.68 Ele serve como uma espécie de rascunho da decisão final. (...) A formação da posição da corte sobre a fundamentação não seria propriamente coletiva, já que o plenário apenas se manifesta ratificando um voto previamente formado individualmente por um dos membros." (ALMEIDA, Danilo dos Santos; BOGOSSIAN, Andre Martins. "Nos termos do voto do relator": considerações acerca da fundamentação coletiva nos acórdãos do STF. REI - Revista Estudos Institucionais, Revista da
} 
Bogossian ressaltam que tal prática, apesar de ser positiva por um lado por proporcionar diversificação nos fundamentos e na própria redação dos acórdãos em função do relator sorteado para determinado caso -, pode minar a deliberação e a busca pelo consenso ${ }^{60}$.

Contudo, considerando o tempo despendido nos julgamentos dos casos de maior repercussão e, consequentemente, a demasiada extensão dos respectivos acórdãos, em que todos os Ministros discorrem longamente sobre argumentos que, não raramente, não são mencionados em todos os votos, torna-se difícil concordar que as razões de decidir serão definidas apenas pelo relator ou pelo primeiro voto vencedor.

Por outro lado, observando-se a prática do STF, não há como negar a importância no imaginário dos Ministros de pronunciar pela primeira vez a posição vencedora, o que implicaria afastar a ideia de que o voto do relator seria "um voto qualquer". Isso porque aquele que defender em primeiro lugar a posição vencedora será o relator para o acórdão - o que pode levar, inclusive, a discussões entre o relator originário e o julgador que proferir o primeiro voto divergente e posteriormente vencedor.

Juliana Cesario Alvim Gomes e Diego Werneck Arguelhes, ao discorrerem sobre o papel do relator, usam como exemplo a discussão travada entre o Ministro Barroso e o Ministro Marco Aurélio na ADPF 291 - em que se analisava o crime de pederastia previsto no Código Penal Militar. Na ocasião, o Ministro Barroso, relator, ao fim do seu voto, ofereceu uma posição intermediária que acolhia o pedido subsidiário da petição inicial, caso a maioria não acompanhasse a que defendera originalmente pela total procedência da ação. Depois de colhidos os votos, formou-se maioria pelo provimento do pedido subsidiário. Enquanto o Ministro Barroso sustentava que adaptaria seu voto para espelhar a opinião da maioria, o Ministro Marco Aurélio alegava que o relator teria ficado

Faculdade Nacional de Direito da UFRJ. Rio de Janeiro, vol. 2, 1, 2016., pp. 293-294; grifos no original).

${ }^{60}$ Ibid. p. 294. 
vencido e que, portanto, ele próprio, Marco Aurélio, deveria ser designado relator para redigir o acórdão ${ }^{61}$.

Partindo desse episódio, Gomes e Arguelhes refletem sobre a postura do relator ao longo da sessão de julgamento, depois de ter proferido seu voto: se deveria ser um "relator-decisor" ou um "relator-articulador". Um relator-decisor busca de todas as formas defender a sua posição, que acredita ser a correta. A despeito da possibilidade de o relator-decisor mudar de opinião, via de regra, sustentará a sua própria mesmo que, ao final, reste vencido. O relator-articulador, por sua vez, busca o máximo de consenso, aceitando, se for o caso, alterar seu posicionamento para se adaptar à opinião da maioria.

Analisando o histórico e o próprio Regimento Interno do STF, os autores asseveram que a regra, no Tribunal, é que o relator se comporte como um relator-decisor, enquanto em outros tribunais estrangeiros, como nos Estados Unidos, o relator luta "para continuar relator até o fim, modulando sua posição para que se torne representativa da maioria"62. Um caso conhecido, por exemplo, em que o relator agiu como relatordecisor foi a Reclamação 4.335, já mencionada no capítulo anterior. Na ocasião, o Ministro Gilmar Mendes, relator, sustentou a tese de mutação constitucional do art. 52, inciso X, da Constituição. A cada voto proferido pelos demais, o relator insistia em emplacar a sua própria tese apesar dos argumentos contrários expostos por seus pares ${ }^{63}$. Ao fim, embora a sua posição específica tenha sido endossada apenas pelo Ministro Eros Grau, o Ministro Gilmar Mendes consagrou-se vencedor unicamente pelo fato de o resultado por ele alcançado - a procedência do pedido - também ter sido atingido por outros Ministros. No entanto, os demais julgadores que compuseram a maioria decisória com relação à procedência, na realidade, acompanharam as razões expostas pelo Ministro Teori Zavascki,

\footnotetext{
${ }^{61}$ STF, ADPF 291, Rel. Ministro Roberto Barroso, Brasília, 28 out. 2015, pp. 89-91.

${ }^{62}$ GOMES, Juliana Cesario Alvim; ARGUELHES, Diego Werneck. Qual o papel do relator no Supremo? Duas respostas em tensão no caso da pederastia. JOTA, 03 nov. 2015. Disponível em https://bit.ly/2IHanYT. Acesso em 22 mai. 2018.

${ }^{63} \mathrm{~V}$. nota de rodapé $\mathrm{n}^{\circ} 37$.
} 
substancialmente diversas daquelas apresentadas pelo relator que, nada obstante isso, ficou responsável por redigir a ementa e incluiu no acórdão a expressão "nos termos do voto do Relator"64.

Com efeito, a maioria dos Ministros entrevistados por Silva apontaram que o relator deve defender a sua própria posição - isto é, portarse como relator-decisor -, com a elaboração de um voto persuasivo, sendo legítimo, por exemplo, inserir apenas a doutrina que lhe é favorável ${ }^{65}$. Nesse sentido, inclusive, vale destacar que, durante as entrevistas, os Ministros admitiram abertamente que privilegiam a própria opinião em detrimento dos fundamentos contrários ${ }^{66}$ - conforme constatado no capítulo anterior.

E isso acontece mesmo com o relator, a quem, idealmente, deveria incumbir a exposição das várias soluções aplicáveis ao caso de forma isenta, a fim de suscitar um franco debate ${ }^{67}$. Isso porque o relator é o juiz que teve maior contato com o caso, com acesso a uma quantidade maior de informações e argumentos, incumbindo-lhe, assim, fornecer todos os dados pertinentes relacionados às posições defendidas no curso do processo aos demais Ministros - que, naturalmente, não terão tempo hábil de analisar a fundo todos os aspectos relativos à matéria ${ }^{68}$. Não é essa, todavia, a prática observada no STF, em que os relatores agem mais como advogados da própria opinião do que como juízes.

A postura de um relator-decisor em um colegiado, portanto, não é a mais ideal para se alcançar efetiva deliberação na fase decisional. Nesse sentido, Gomes e Arguelhes reconhecem que, para fins de deliberação colegiada, a figura de um relator-articulador parece ser a mais adequada.

\footnotetext{
${ }^{64}$ STF, Rcl 4.335, Rel. Ministro Gilmar Mendes, Brasília, 20 mar. 2014.

${ }^{65}$ SILVA, Virgílio Afonso da. 'Um Voto Qualquer'? O papel do ministro relator na deliberação no Supremo Tribunal Federal. REI - Revista Estudos Institucionais: Revista da Faculdade Nacional de Direito da UFRJ, v. 1, 2015, p. 196.

66 “(...) a percepção dominante é a de que 'são raros os momentos em que isso [a exposição de argumentos contrários] ocorre', de que 'normalmente nós procuramos construir o nosso voto com a doutrina que chancela o nosso entendimento; dificilmente nós levamos correntes diferentes', enfim, de que suscitar o debate franco, simplesmente 'não é a regra'." (Ibid. p. 196)

${ }^{67}$ Ibid. p. 195.

68 SILVA, Virgílio Afonso da. Deciding Without Deliberating. International Journal of Constitutional Law, Oxford University Press, v. 11, 2013, p. 577.
} 
Todavia, ressaltam que, nesse caso, seria necessário que essa função estivesse claramente estabelecida para todos os julgadores, a fim de evitar problemas tais como o caso em que um Ministro segue o relator e, depois que este altera minimamente seu entendimento para se adequar à decisão do colegiado, aquele não concorda com a mudança de posicionamento ${ }^{69}$.

Em suma, um relator, mais do que defensor de suas próprias ideias a qualquer custo, deveria ser a figura central que promove, desde o relatório, as bases para o debate colegiado. Para tanto, alguns mecanismos podem ser aplicados pelo relator para auxiliar a deliberação na fase decisional, principalmente nos casos mais relevantes: (i) exposição e enfrentamento dos principais argumentos relacionados à matéria a ser julgada, tanto os favoráveis quanto os contrários à posição defendida; (ii) delimitação das questões jurídicas a serem debatidas, conforme será analisado no capítulo seguinte; (iii) distribuição prévia do voto a seus pares; e (iv) adoção da postura de um relator-articulador, em busca de uma decisão verdadeiramente colegiada, desde que essa função esteja bem clara para todos.

Esses mecanismos, no entanto, não serão suficientes sem a colaboração dos demais Ministros, cuja conduta será examinada na próxima subseção.

\subsubsection{Demais Ministros: a manifestação sem declaração de voto, o voto pronto e suas repercussões}

Para que uma decisão seja efetivamente colegiada, a participação dos demais julgadores no processo deliberativo é primordial. Caso contrário, bastaria o voto do relator para solucionar o caso. Contudo, duas práticas completamente opostas e amplamente utilizadas no STF podem acarretar problemas para a deliberação na fase decisional: a manifestação sem

\footnotetext{
${ }^{69}$ GOMES, Juliana Cesario Alvim; ARGUELHES, Diego Werneck. Op. cit.
} 
declaração de voto, registrada apenas em ata de julgamento, e o voto pronto.

Utilizando a expressão de Virgílio Afonso da Silva, nos casos menos importantes - e que assoberbam o STF -, é comum que o relator apresente seu voto e, em seguida, os demais juízes apenas sigam a posição do relator, sem qualquer acréscimo ou comentário. É claro que existe a possibilidade de o pronunciamento do relator articular fundamentos compartilhados pelos demais julgadores. Todavia, Carlos Ari Sundfeld e Henrique Motta Pinto ressaltam que não é possível verificar se a mera adesão ao voto condutor se dá em razão da concordância com o resultado apenas ou se se compartilham de fato os argumentos elencados ${ }^{70}$.

Consequentemente, os autores afirmam que essa prática, ao deixar desconhecidos os verdadeiros motivos que levam ao resultado, "[substituise] à atividade de construção colegiada da convicção" ${ }^{71}$. Em razão disso, a opinião do relator - e, mais especificamente, a sua fundamentação - passa a equivaler ao entendimento do próprio Tribunal, podendo acarretar problemas futuros quanto à aplicação do precedente formado "na medida em que as razões constitucionais ali expressas não são compartilhadas pela maioria dos ministros" $" 72$.

Uma das explicações para o elevado número de manifestações sem voto $^{73}$, segundo Carlos Ari Sundfeld e Rodrigo Pagani de Souza, poderia ser o enorme volume de trabalho, que impediria os Ministros de dedicarem tempo à maioria dos casos, elegendo apenas os mais relevantes para se debruçarem de forma mais detida sobre a matéria analisada ${ }^{74}$.

\footnotetext{
${ }^{70}$ SUNDFELD, Carlos Ari; PINTO, Henrique Motta. Três Desafios para Melhorar a Jurisdição Constitucional Brasileira. In: VOJVODIC, Adriana (Org.); PINTO, Henrique Motta (Org.); GORZONI, Paula (Org.); SOUZA, Rodrigo Pagani de (Org.). Jurisdição Constitucional no Brasil. São Paulo: Malheiros Editores, 2012. p. 25.

${ }^{71}$ Ibid. p. 28.

${ }^{72}$ Ibid. p. 28.

${ }^{73}$ Na pesquisa conduzida por Sundfeld e Souza de 267 acórdãos de ações de controle concentrado, por exemplo, "dos 2.242 votos dos ministros não relatores mapeados na pesquisa, 1.338, ou cerca de 60\%, foram dados por manifestações sem declaração de voto (apenas registradas em ata de julgamento)" (Ibid. p. 87)

${ }^{74}$ Ibid. pp. 87-88.
} 
No entanto, conforme constatado por Silva, aludir apenas ao volume de trabalho para justificar a ausência de votos mostra-se incompatível com a crescente prática de se redigirem votos extremamente longos em casos de maior repercussão ${ }^{75}$. Afinal, a prática de levar votos prontos para as sessões de julgamento ocupa não só o tempo de cada Ministro anteriormente, como também o tempo durante a própria sessão, em que não raramente apenas um caso é apreciado devido à prática do Tribunal de o julgamento se resumir à leitura oral de cada uma das posições individuais.

Nesse sentido, diversas outras críticas podem ser tecidas com relação ao voto pronto. Em primeiro lugar, a prática em si de redigir um voto inteiramente articulado, com amplo embasamento doutrinário e jurisprudencial, fora do âmbito do colegiado já é colocada como obstáculo à deliberação na fase decisional. Uma vez armado de um voto complexo, longo e que demandou uma quantidade razoável de tempo, será muito mais difícil, posteriormente, eventual mudança de entendimento por parte do julgador provocada pelo debate que deveria ser travado durante a interação colegiada. Essa dificuldade, inclusive, foi pontuada por vários Ministros entrevistados por Silva ${ }^{76}$, mesmo por aqueles que aderem a essa prática ${ }^{77}$.

Por outro lado, houve aqueles que defenderam ser algo natural chegar à sessão preparado após um trabalho de pesquisa mais denso, espelhado em um voto já redigido ${ }^{78}$. Contudo, afirmar que os votos não deveriam ser estruturados anteriormente ao momento de interação colegiada não impede um estudo prévio mais detalhado dos aspectos relativos à matéria, podendo o Ministro levar anotações para a sessão, como

\footnotetext{
75 SILVA, Virgílio Afonso da. Deciding Without Deliberating. International Journal of Constitutional Law, Oxford University Press, v. 11, 2013, p. 578.

76 "Essa visão é compartilhada por vários ministros, que argumentam que quem leva um voto pronto tende a 'não querer refletir e querer brigar pelo seu voto', e que 'o debate [acaba] sendo irrelevante, porque o sujeito já vem comprometido com uma linha'.” (Id., 'Um Voto Qualquer'? O papel do ministro relator na deliberação no Supremo Tribunal Federal. REI - Revista Estudos Institucionais: Revista da Faculdade Nacional de Direito da UFRJ, v. 1, 2015. p. 191).

${ }^{77}$ É interessante destacar que os ex-Ministros entrevistados se posicionaram contra a atitude de levar votos prontos às sessões, tendo um deles afirmado que a prática é "mais do que errada" (Ibid. p. 192).

${ }^{78}$ Ibid. p. 192
} 
costumava ser feito há não muito tempo ${ }^{79}$. Munir-se de anotações, todavia, é substancialmente diferente de concatenar e estruturar seus fundamentos em um texto. Isso porque, uma vez ouvidos os demais pronunciamentos, será muito mais fácil confrontá-los com meras notas para verificar se seria a hipótese ou não de mudar seu próprio entendimento, ao contrário da situação em que já se possui um voto inteiro, com começo, meio e fim.

Vale destacar que, além da longa extensão dos votos, há Ministros que incluem, antes da sua manifestação propriamente dita, um relatório do caso $^{80}$, diverso daquele apresentado pelo relator, atuando, nas palavras de um dos entrevistados por Silva, "como se relator fosse" $"$. Enquanto, de um lado, pode-se considerar apenas uma estratégia para organizar melhor o próprio voto, por outro lado, levantam-se duas questões: $(i)$ o tempo que se gasta elaborando essa parte - quando já existe um relatório escrito por aquele que tem mais familiaridade com o caso - e, principalmente, (ii) o fato de um voto inteiro partir de fatos e informações descritos e percebidos de forma diferente do que se disponibiliza para todos os membros do colegiado, fazendo cair por terra a função do relatório original, que deveria fornecer os subsídios para que a decisão partisse de uma base comum. Se o Ministro que assim age teve acesso ao relatório oficial, torna-se desnecessário elaborar o seu próprio. Se ele não procedeu à sua leitura, essa atitude será ainda mais prejudicial à deliberação. Isto é, em qualquer hipótese, a elaboração de um segundo relatório carece de qualquer sentido.

A prejudicialidade da prática do voto pronto é ainda agravada pelo fato de o voto do relator, na maioria das vezes, ser revelado apenas no

\footnotetext{
${ }^{79}$ Ibid. p. 192. A título de curiosidade, transcreve-se um comentário do Ministro Dias Toffoli durante o julgamento da ADC 41: "Senhora Presidente, eu sempre fico um pouco constrangido de ler voto para acompanhar o Relator, sem crítica a qualquer um, porque, de vez em quando, o Ministro Pertence (...) me pergunta: "Vocês mudaram o regimento no Supremo?" Aí, eu pergunto: "Em que ponto?" "Agora é obrigado, para acompanhar o Relator, fazer-se um voto e, às vezes, maior do que o do próprio Relator?" - só para descontrair um pouco". Em seguida, o Ministro Marco Aurélio acrescentou: "Digo a Vossa Excelência que a expressão, do passado, "de acordo", pelo vogal, não está em moda" (STF, ADC 41, Rel. Ministro Roberto Barroso, Brasília, 08 jun. 2017, p. 125).

${ }^{80}$ A título ilustrativo, cite-se o voto do Ministro Barroso na ADI 4.983 - em que se discutia a constitucionalidade ou não da vaquejada - que se iniciava com um relatório distinto do que aquele elaborado pelo próprio relator do caso, Ministro Marco Aurélio.

${ }^{81}$ SILVA, Virgílio Afonso da. Op. cit., 192.
} 
julgamento. Desse modo, no momento em que os outros Ministros se dedicam a estruturar um voto, eles sequer conhecem a posição e os argumentos levantados pelo relator. Segundo Silva, o fato de se formar, de antemão, uma posição praticamente hermética já é, por si só, antideliberativa, em razão da ausência - ou quase ausência - de diálogo entre os votos, seja com relação ao do relator, seja com relação aos demais $^{82}$.

A dinâmica das sessões em si também é um critério que dificulta a deliberação entre os magistrados. Na realidade, mais do que uma sessão de julgamento, trata-se de sessão de leitura de votos cada vez mais extensos, que tomam tempo demasiadamente desnecessário por meio de digressões ou construções de verdadeiras teses doutrinárias, com pouco ou nenhum debate oral entre os Ministros. Impede-se, assim, a saudável troca de ideias que deveria permear uma decisão colegiada. É verdade que há momentos em que existe um mínimo de diálogo durante a leitura de algum voto, mas na maioria das vezes as discussões recaem sobre questões pontuais, sem qualquer estímulo para que se construa uma solução conjuntamente ao invés de tentar simplesmente convencer o outro da sua própria visão ${ }^{83}$.

Configurando-se apenas um momento de leitura de posições já formadas, Silva sublinha outra consequência, referente aos votos que não seguem a maioria. Segundo o autor, há uma diferença entre voto divergente e voto vencido. Este seria meramente uma posição dissidente, sem estabelecer qualquer diálogo com a opinião majoritária, enquanto aquele buscaria efetivamente apresentar um contraponto, identificando quais seriam as eventuais falhas no raciocínio da maioria ${ }^{84}$. No âmbito do STF, portanto, o autor considera que existem meramente votos vencidos, que

\footnotetext{
${ }^{82}$ Id., Deciding Without Deliberating. International Journal of Constitutional Law, Oxford University Press, v. 11, 2013, p. 570.

${ }^{83}$ Ibid. p. 576. SUNDFELD, Carlos Ari; PINTO, Henrique Motta. Op. cit., p. 24.

${ }^{84}$ SILVA, Virgílio Afonso da. De Quem Divergem os Divergentes: os Votos Vencidos no Supremo Tribunal Federal. Direito, Estado e Sociedade: Revista do Departamento de Direito da PUC-Rio, n. 47, 2015, p. 217.
} 
ficam registrados nos anais do Tribunal, sem a capacidade de influenciar na decisão tomada ${ }^{85}$.

$\mathrm{O}$ que as posturas tanto do relator-decisor quanto dos demais Ministros revelam é um extremo individualismo ${ }^{86}$, indo totalmente de encontro ao próprio sentido de colegialidade, já que denota ausência de cooperação, de disposição de atuar como um time, de se apresentar para o mundo externo como uma verdadeira instituição e, em determinados casos, de respeito com relação aos seus pares ${ }^{87}$.

Nada obstante isso, é interessante observar que a ideia de colegialidade está, de alguma forma, presente no consciente dos Ministros. No julgamento do HC 152.752 - impetrado para afastar a execução provisória de sentença penal condenatória após decisão de segunda instância sem trânsito em julgado -, por exemplo, a Ministra Rosa Weber pautou grande parte de seu voto sobre o princípio da colegialidade, acerca do qual assim discorre:

"Em uma segunda dimensão, a colegialidade, quanto ao seu elemento funcional, exige a direta interação, por meio do respeito e confiança recíprocos, entre os membros do grupo para a formação da vontade coletiva, que não se perfectibiliza

\footnotetext{
85 Id., Deciding Without Deliberating. International Journal of Constitutional Law, Oxford University Press, v. 11, p. 557-584, 2013, p. 575 e p. 584.

${ }^{86}$ Sunfeld e Pinto constatam que esse individualismo é espelhado na própria estrutura dos votos de cada Ministro, que determinam determinados tipos de citações e referências em detrimento de outros, sendo comum, ainda, que façam alusão apenas a decisões de sua própria relatoria. (SUNDFELD, Carlos Ari; PINTO, Henrique Motta. Op. cit., p. 25). Note-se, ainda, que os Ministros entrevistados por Silva também reconhecem esse extremo individualismo, contudo, conforme ressaltado pelo autor, "a identificação desse problema [excesso de individualismo], curiosamente, não tem reflexos na visão que os ministros têm acerca da prática de sempre escrever votos individuais, longos ou curtos, divergentes ou concorrentes" (SILVA, Virgílio Afonso da. De Quem Divergem os Divergentes: os Votos Vencidos no Supremo Tribunal Federal. Direito, Estado e Sociedade: Revista do Departamento de Direito da PUC-Rio, n. 47, 2015, p. 224).

${ }^{87}$ No final de 2017 e no início de 2018, testemunharam-se momentos de trocas de fervorosas críticas entre alguns Ministros do STF, nomeadamente entre o Ministro Gilmar Mendes e o Ministro Barroso (ADI 5.763 e ADI 5.394), e entre o Ministro Marco Aurélio e as Ministras Carmen Lúcia e Rosa Weber (HC 152.752). A despeito da existência de posicionamentos distintos e de ressalvas pessoais - o que é natural -, é inegável que tais episódios causaram perplexo em muitos, ao denotarem uma clara ausência de cooperação entre magistrados que deveriam atuar em conjunto como instituição. Independentemente da opinião que se possa ter com relação a determinados Ministros, momentos semelhantes apenas dificultam a vontade de trabalhar como um time e, em última instância, a deliberação.
} 
com a soma de várias vozes, e sim com a sua conjugação em uníssono, a voz da Corte para toda sociedade a conformar a ordem normativa constitucional." ${ }^{88}$

Entretanto, apesar de reconhecer a exigência de interação entre os membros do órgão colegiado, a própria Ministra agiu contrariamente ao seu próprio argumento ${ }^{89}$, na medida em que (i) elaborou seu pronunciamento antes da sessão de julgamento, (ii) sem conhecer o teor do voto do relator, (iii) preenchendo vinte e seis páginas com seu voto, (iv) cuja leitura demorou uma hora, com breves interrupções. Ademais, por mais que algumas partes de seu voto se aproximassem dos argumentos ventilados pelo Relator Ministro Edson Fachin, a Ministra (v) não estabeleceu efetivo diálogo com o voto condutor - o qual, na conclusão de sua fala, acompanhou na íntegra. Ou seja, ao mesmo tempo em que a fundamentação de seu voto aludia à colegialidade, o individualismo prevaleceu na sua postura durante o julgamento - assim como na de outros Ministros na mesma ocasião.

Seja nos casos em que apenas o relator discorre sobre seus fundamentos e os demais se manifestam sem declaração de voto, seja nos casos em que todos, ou quase todos, elaboram previamente seu próprio voto, o que se percebe é a ausência de diálogo - e, portanto, de deliberação - nas sessões de julgamento do STF. E, contrariamente ao que se poderia alegar, soluções simples, mas significativas, poderiam minimizar esse problema a despeito do enorme volume de trabalho do Tribunal.

Primeiramente, deve-se extinguir ou reduzir ao máximo a quantidade de votos prontos, otimizando, assim, o tempo dos Ministros, que poderão analisar minimamente também os casos menos importantes. Tendo tido acesso ao voto do relator previamente, bastaria esboçar algumas notas e,

\footnotetext{
${ }^{88}$ STF, HC 152.752, Rel. Ministro Edson Fachin, Brasília, 05 abr. 2018. Apesar de o acórdão ainda não ter sido publicado, o voto da Ministra Rosa Weber já está disponível (S.N. Leia voto Ministra Rosa Weber. Revista Consultor Jurídico. Disponível em https://bit.ly/2kjek71. Acesso em 22 mai. 2018; pp. 11-12).

${ }^{89}$ Não se trata, aqui, de qualquer espécie de julgamento, positivo ou negativo, quanto ao mérito do voto da Ministra. Pretende-se apenas demonstrar, por meio de um exemplo, que a forma como os Ministros do STF agem durante a fase de interação colegiada prejudica a deliberação.
} 
eventualmente, aprofundar algumas pesquisas, contudo sem estruturar inteiramente um voto. Assim, durante a sessão, seria possível reduzir e simplificar as falas, que partiriam do voto do relator para tecer considerações próprias.

Além disso, os debates orais deveriam ser mais estimulados para apresentar contrapontos e fazer um esforço coletivo a fim de se chegar efetivamente a uma decisão do colegiado, demonstrando um compromisso com a instituição em si, em detrimento do individualismo. E isso deve ser aplicado, na medida do possível - admitindo-se graus distintos -, em todos os casos, independentemente de sua importância, evitando, dessa forma, manifestações sem declaração de voto nas situações em que não se concorda com os fundamentos apresentados pelo relator.

Enquanto não houver um mínimo de observância dos padrões de deliberação na fase decisional, a consequência será a falta de uma decisão institucional e colegiada, com reflexos na fase pós-decisional. Isso porque, nas situações em que apenas o relator se pronuncia, a ratio decidendi será extraída integralmente de seu voto. Já nas hipóteses em que todos redigem seu próprio voto antecipadamente, a enorme dificuldade será tentar identificar as razões de decidir do precedente firmado - objeto de análise do capítulo subsequente. 


\section{Capítulo 3 - Redação e aplicação dos precedentes do STF}

\subsection{Dispersão de fundamentos: problemas quanto à identificação da ratio decidendi}

Uma vez tomada a decisão pelo colegiado, passa-se à fase pósdecisional. Caso a maioria ou todos os Ministros tenham seguido o voto do relator, o próprio relator ficará incumbido de redigir o acórdão. Se ele, todavia, restar vencido, o primeiro a ter proferido o voto vencedor será designado redator do acórdão.

Na realidade, o responsável por redigir o acórdão terá como função apenas elaborar a ementa, visto que se adota, no STF, o modelo seriatim de decisão, em que constam todos os votos proferidos. Assim, cada Ministro enviará seu próprio voto por escrito à central de acórdãos do Tribunal, podendo, inclusive, decidir pela exclusão ou não de intervenções suas durante os debates orais. Não há, portanto, atuação do colegiado nessa etapa; em outras palavras, inexiste deliberação e a decisão final escrita será, nas palavras de Conrado Hübner Mendes, uma mera "colcha de retalhos", que "sequer consegue fornecer uma ratio decidendi compartilhada, um precedente que de fato oriente casos futuros" $"$.

O efeito direto da falta de deliberação na fase decisional, principalmente nos casos mais importantes em que os Ministros discorrem longamente sobre suas próprias posições, é justamente a dificuldade de se identificar a ratio decidendi da decisão, isto é, os fundamentos centrais que levaram o colegiado como um todo a determinada solução. Isso decorre da falta de incentivo para se estabelecer um verdadeiro diálogo entre as opiniões defendidas, visto que só há preocupação com relação ao resultado da decisão.

\footnotetext{
90 "Uma seriatim não deliberativa, nessa perspectiva, assemelha-se a uma colcha de retalhos decisões individuais coladas lado a lado, que não conversam entre si. A falta de comunicação entre as opiniões dificulta, ademais, a realização das promessas formais do Estado de Direito, pois sequer consegue fornecer uma ratio decidendi compartilhada, um precedente que de fato oriente casos futuros" (MENDES, Conrado Hübner. Op. cit, p. 66).
} 
Fábio Carvalho Leite e Marcelo Santini Brando, ao analisarem a questão da dispersão de fundamentos no âmbito de ações de controle concentrado, investigaram algumas possíveis causas para o fenômeno. Em primeiro lugar, os autores destacam que, segundo o art. 173, do Regimento Interno do $\mathrm{STF}^{91}$, a maioria absoluta exigida pelo art. 97, da Constituição Federal de $1988^{92}$, para a declaração de inconstitucionalidade de uma lei se refere apenas ao resultado e não aos fundamentos. Consequentemente, "se os fundamentos não importam, aumentam as chances de dispersão" 93 .

Além disso, segundo os autores, outra explicação para a dispersão de fundamentos especificamente em ADI e ADPF é a causa de pedir aberta, que permite um espectro maior de análise, visto que, independentemente dos dispositivos constitucionais apontados pelo autor da ação como violados, o Tribunal poderá declarar a norma incompatível com a Constituição com base em outras normas ${ }^{94}$. Por fim, aludem à indeterminação relativa do texto constitucional, que pode ser ocasionada pela textura aberta e vagueza da linguagem, por antinomias ou lacunas e por outros fatores que influenciarão na interpretação e na delimitação do alcance da norma ${ }^{95}$.

Com relação às três causas, Leite e Brando afirmam que as práticas em si não são necessariamente positivas ou negativas, existindo motivos contextuais por trás de cada uma delas ${ }^{96}$. Nada obstante, independentemente

\footnotetext{
91 RISTF, art. 173: "Efetuado o julgamento, com o quorum do art. 143, parágrafo único, proclamar-se-á a inconstitucionalidade ou a constitucionalidade do preceito ou do ato impugnados, se num ou noutro sentido se tiverem manifestado seis Ministros".

${ }^{92}$ CRFB, art. 97: "Somente pelo voto da maioria absoluta de seus membros ou dos membros do respectivo órgão especial poderão os tribunais declarar a inconstitucionalidade de lei ou ato normativo do Poder Público".

${ }^{93}$ LEITE, Fábio Carvalho; BRANDO, Marcelo Santini. Dispersão de fundamentos no Supremo Tribunal Federal. Direito, Estado e Sociedade: Revista do Departamento de Direito da PUC-Rio. Rio de Janeiro, n. 48, 2016, p. 143.

${ }^{94}$ Ibid. p. 143.

${ }^{95}$ Ibid. p. 144-145. Quanto à textura aberta, v. nota de rodapé ${ }^{\circ} 34$.

${ }^{96}$ No caso da preocupação apenas com o resultado e não com a fundamentação, por exemplo, os autores afirmam que essa prática pode conferir maior operacionalidade à atuação do STF (Ibid. p. 143). A questão da causa de pedir aberta se refere à própria natureza objetiva das ações de controle concentrado, evitando que o Tribunal seja proibido de declarar uma norma inconstitucional somente pelo fato de o fundamento considerado correto não ter sido alegado pelo autor da ação (Ibid. p. 144). Quanto ao último ponto, a vagueza da linguagem permite que o texto constitucional se adapte mais facilmente às mudanças da sociedade (Ibid. p. 145).
} 
de tais motivos, fato é que esses fatores aumentam a possibilidade de dispersão de fundamentos entre os votos. Contudo, em meio aos três, o que mais se destaca, consoante os autores, é a formação do quórum tão somente com relação à conclusão, ignorando-se os argumentos utilizados por cada julgador. Isso porque, em um cenário em que a regra fosse a vinculação da maioria decisória aos fundamentos, "não parece importar se o texto constitucional é determinado, nem se a causa de pedir é aberta ou fechada"97.

A dificuldade de identificação da ratio decidendi da decisão do Tribunal não é exclusiva de ações de controle concentrado. Adriana Vojvodic, Ana Mara França Machado e Evorah Luci Costa Cardoso, por exemplo, ao analisarem casos em que o fenômeno da dispersão de fundamentos se mostrou latente, incluíram o HC 82.424, também conhecido como "caso Ellwanger", que versava sobre o crime de racismo. Apesar de um aparente diálogo entre os votos dos Ministros, as autoras observam que não houve sequer convergência para identificar a questão jurídica central que deveria ser decidida, eis que as posições defendidas por cada Ministro se relacionavam a uma dentre três problemáticas distintas ${ }^{98}$.

Por outro lado, em casos envolvendo matérias teoricamente mais polêmicas, tais como liberdade, autonomia e igualdade, não é raro encontrar resultados unânimes, girando em torno de argumentos bastante semelhantes, em caminho oposto ao que se encontra em outros países. É o que sublinham Diego Werneck Arguelhes e Leandro Molhano Ribeiro, segundo os quais "[o] Supremo parece se dividir mais em função de conjunturas, do contexto, e não de grandes temas constitucionais" ${ }^{99}$. Dois exemplos recentes em que houve maior grau de concordância com relação

\footnotetext{
${ }^{97}$ Ibid. p. 147.

98 VOJVODIC, Adriana de Moraes; MACHADO, Ana Mara França; CARDOSO, Evorah Luci Costa. Escrevendo um romance, primeiro capítulo: precedentes e processo decisório no STF. Revista Direito GV, São Paulo, v. 9, 2009, p. 32.

${ }^{99}$ Como exemplos, os autores citam os casos Cesare Battisti, Antonio Palocci, a obrigatoriedade de transcrição de gravações oriundas de interceptação telefônica, a amplitude dos poderes de investigação do CNJ e a Lei da Ficha Limpa (ARGUELHES, Diego Werneck; RIBEIRO, Leandro Molhano. Quando a unanimidade não esclarece. Valor Econômico, Rio de Janeiro, 22 jun. 2012).
} 
às razões de decidir envolviam justamente liberdade de expressão e igualdade; são eles, respectivamente, a ADI 4.815, sobre biografias não autorizadas, e a ADC 41, acerca da reserva de vagas para negros em concurso público ${ }^{100}$.

Arguelhes e Ribeiro, entretanto, advertem que, embora a unanimidade seja positiva por transmitir uma mensagem estabilizadora sobre temas que costumam dividir a opinião pública, ela pode ser negativa caso tenha sido construída sem um efetivo diálogo com as diversas opiniões envolvidas ${ }^{101}$. No caso das biografias não autorizadas, a maioria dos votos abordaram os argumentos contrários à posição sustentada ${ }^{102}$; já no caso da reserva de vagas para negros em concurso público, os Ministros priorizaram os fundamentos que lhes eram favoráveis, mesmo que se tratasse de uma ADC, cujo requisito imprescindível é a existência de controvérsia judicial relevante, nos termos do art. 14, inciso III, da Lei $n^{\circ}$ 9.868/99103.

Não obstante os casos em que se verifica maior grau de unanimidade entre a motivação dos votos, a fundamentação dispersa se encontra presente em muitas outras decisões envolvendo questões constitucionais mais complexas, tais como a pesquisa com células-tronco embrionárias (ADI 3.510), os limites do direito de reunião (ADI 1.969) e a aplicação do Código de Defesa do Consumidor às instituições bancárias (ADI 2.591) ${ }^{104}$, tendo como consequência a dificuldade de se identificar a ratio decidendi.

\footnotetext{
${ }^{100}$ No caso da ADC 41, embora os fundamentos para a constitucionalidade da política afirmativa de reserva de vagas para negros tenham sido semelhantes, houve algumas diferenças de opinião, tais como a forma de controle de fraudes e a extensão da decisão para outros entes além da União. 101 Ibid.

${ }^{102}$ Em contrapartida, na ADI 4.815, quase todos os Ministros elaboraram extensos votos escritos, frequentemente repetindo argumentos já enfrentados longamente no voto da relatora, Ministra Carmen Lúcia, que foi distribuído aos seus pares antes da sessão de julgamento. Embora tenha havido debates orais durante a sessão, observando-se maior deliberação na fase decisional, há pouco ou quase nenhum diálogo entre os votos escritos, posteriormente juntados. Assim, a decisão final escrita - isto é, o produto da etapa pós-decisional - não obedece integralmente aos padrões exigentes de deliberação consoante o ideal de corte deliberativa desenhado por Conrado Hübner Mendes.

${ }^{103}$ Lei n ${ }^{\circ}$ 9.868/99, art. 14: "A petição inicial indicará: III - a existência de controvérsia judicial relevante sobre a aplicação da disposição objeto da ação declaratória."

${ }^{104}$ Quanto às ADIs 3.510 e 2.591, v. LEITE, Fábio Carvalho; BRANDO, Marcelo Santini. Op. cit., pp. 140-141. As três ADIs mencionadas também são comentadas por Vojvodic, Machado e Cardoso (VOJVODIC, Adriana de Moraes; MACHADO, Ana Mara França; CARDOSO, Evorah Luci Costa. Op. cit., pp. 23-24; pp. 28-31; 33-36).
} 
Essa dificuldade tem repercussão tanto nas decisões futuras do próprio STF sobre a matéria quanto na aplicação dos precedentes pelos demais operadores do direito. A primeira hipótese se refere ao fato de os próprios Ministros não serem capazes de pincelar com exatidão qual a real jurisprudência do Tribunal sobre o assunto. Carlos Ari Sundfeld e Henrique Motta Pinto, desse modo, ressaltam que a produção anterior do STF "não é fator influente na determinação do resultado e das razões respectivas do novo julgamento" 105 . A inclusão de precedentes nos votos, portanto, servirá apenas para fins argumentativos, sem o intuito de inserir o caso analisado no contexto jurisprudencial da Corte ${ }^{106}$.

Devido à dificuldade de apontar o estado de jurisprudência, não há coerência entre as decisões que versam sobre a mesma matéria. Afinal, tendo cada Ministro seguido uma linha argumentativa diferente, abre-se margem para que outros magistrados e os próprios Ministros utilizem a linha que melhor thes aprouver em casos futuros, de forma isolada ${ }^{107}$. Posteriormente, podem ocorrer duas situações distintas: (i) o Tribunal, em razão das diferentes linhas de raciocínio aplicadas, pode ser instado a declarar com maior precisão qual argumento deve prevalecer ${ }^{108}$; ou (ii) diante de mudanças no contexto, pode surgir a necessidade de mudar o entendimento e a interpretação normativa. No último caso, tratando-se de mudança de jurisprudência, o ônus argumentativo é naturalmente maior, acarretando uma obrigação de delinear um histórico das decisões sobre o tema ${ }^{109}$. No entanto, se não é possível identificar o estado de jurisprudência, torna-se muito mais difícil construir esse histórico, podendo influenciar na legitimidade da fundamentação utilizada.

A dificuldade de identificação do estado de jurisprudência também repercute fora do âmbito do STF. Quando um aplicador do direito deseja

\footnotetext{
${ }^{105}$ SUNDFELD, Carlos Ari; PINTO, Henrique Motta. Op. cit., p. 29.

106 Ibid. p. 31.

107 VOJVODIC, Adriana de Moraes; MACHADO, Ana Mara França; CARDOSO, Evorah Luci Costa. Op. cit., p. 38.

${ }^{108}$ Ibid. p. 38

${ }^{109}$ Ibid. p. 36.
} 
utilizar o precedente formado para um caso futuro, o que importa são as razões de decidir e não o resultado da decisão. Ocorre que, em muitos casos, nem a ementa nem a leitura integral dos votos será suficiente para conhecer a posição do Tribunal sobre o objeto apreciado. Para advogados, juízes, demais tribunais e até mesmo membros da administração pública e da sociedade como um todo, a dificuldade reside em saber efetivamente a jurisprudência do Supremo ${ }^{110}$.

Isso adquire especial relevância a partir da ideia de força vinculante dos precedentes, explicitamente positivada no Código de Processo Civil, cujo art. $927^{111}$, por exemplo, determina de forma expressa a obrigação de juízes e tribunais aplicarem determinados precedentes, como as decisões do STF em sede de controle concentrado ( $c f$. inciso I), os enunciados de súmula vinculante ( $c f$. inciso II) e de súmula de matéria constitucional ( $c f$. inciso IV). Todavia, como aplicar um precedente se se desconhece o seu real fundamento ${ }^{112}$ ?

Além da falta de comunicação entre os votos - o que, por si só, já é suficiente para descaracterizar o STF como uma corte não deliberativa ${ }^{113}-$,

\footnotetext{
110 "O segundo problema da RMDS [regra de maioria decisória simples, isto é, com base apenas no resultado e não nos fundamentos] reside na criação de barreiras ao estabelecimento de precedentes capazes de formar uma jurisprudência. No campo do direito constitucional, especialmente no cenário dos casos difíceis, a decisão tomada pela Corte deveria desempenhar um importante papel de orientação de condutas, tantos para os cidadãos quantos para os demais órgãos do poder público e do Poder Judiciário. Contudo, fica a indagação: 'como influenciar cortes inferiores se não é possível reconhecer qual é a decisão do STF?'.” (LEITE, Fábio Carvalho; BRANDO, Marcelo Santini. Op. cit., p. 152; grifos no original).

${ }^{111}$ CPC/2015, art. 927: "Os juízes e os tribunais observarão: I - as decisões do Supremo Tribunal Federal em controle concentrado de constitucionalidade; II - os enunciados de súmula vinculante; III - os acórdãos em incidente de assunção de competência ou de resolução de demandas repetitivas e em julgamento de recursos extraordinário e especial repetitivos; IV - os enunciados das súmulas do Supremo Tribunal Federal em matéria constitucional e do Superior Tribunal de Justiça em matéria infraconstitucional; V - a orientação do plenário ou do órgão especial aos quais estiverem vinculados."

${ }^{112}$ Quanto aos enunciados de súmula, Leite e Brando criticam redações que se limitam a indicar, por exemplo, que determinada lei é inconstitucional, sem transmitir a ratio decidendi dos julgados que levaram à essa conclusão, o que impede a sua aplicação para casos futuros semelhantes. Como exemplos, citam as súmulas vinculantes $\mathrm{n}^{\circ} 6,8,9,21,28,29$ e 31. Como contrapartida, mencionam a súmula vinculante $\mathrm{n}^{\circ} 12$, que de fato indica o fundamento jurídico - no caso, o dispositivo constitucional violado pela cobrança de taxa em matrícula de universidades públicas (Ibid. p. 154).

113 “(...) esta [seriatim deliberativa] contém múltiplas vozes que, diferentemente da sua versão não deliberativa, ao menos conversam entre si. Em vez de uma colcha de retalhos esgarçada, as opiniões individuais são costuradas de maneira mais explícita. Argumentos mútuos são
} 
a própria extensão de cada manifestação, capaz de resultar em um acórdão com centenas de páginas, é prejudicial. Afinal, segundo leciona Rafael Lorenzo-Fernandez Koatz, a redação final deve se mostrar acessível a todos, juristas ou não, a fim de que as decisões do STF possam ser "lidas, entendidas, difundidas, discutidas, aceitas e respeitadas" ${ }^{114}$. Considerandose o pouco tempo disponível que se tem hoje em dia, Koatz aponta que votos demasiadamente longos, além de serem injustificáveis independentemente da complexidade da matéria discutida, não cumprem esse papel ${ }^{115}$.

Percebe-se, assim, a importância (i) de reduzir a extensão dos acórdãos - o que implica necessariamente a diminuição das próprias manifestações individuais -, a fim de que a decisão final seja acessível a todos; e, sobretudo, (ii) de se estabelecer como regra em todos os julgamentos a vinculação da maioria decisória à fundamentação e não somente ao resultado. A fim de que isso seja espelhado na redação final, isto é, na fase pós-decisional, propõe-se na próxima seção uma deliberação quanto à(s) tese(s) da decisão, o que, em última instância, deverá compor a ementa.

\subsection{Deliberação quanto à(s) tese(s) da decisão: uma proposta em construção}

A principal fonte de jurisprudência para os aplicadores do direito é a ementa da decisão. Contudo, na prática, a maior parte das ementas são meros resumos do voto do relator para o acórdão ${ }^{116}$. Assim, muitas vezes não representam as opiniões de outros Ministros que, apesar de terem

enfrentados, objeções são respondidas e posições são assumidas” (MENDES, Conrado Hübner. Op. cit., p. 67).

114 KOATZ, Rafael Lorenzo-Fernandez. Deliberação e procedimento no Supremo Tribunal Federal: propostas para um modelo de deliberação compatível com a Constituição de 1988. In BAPTISTA, Patrícia (Org.); BRANDÃO, Rodrigo (Org.). Coleção Direito UERJ 80 Anos Direito Público. Rio de Janeiro: Freitas Bastos, v. 8, 2015, p. 456.

115 Ibid. p. 455.

116 VOJVODIC, Adriana de Moraes; MACHADO, Ana Mara França; CARDOSO, Evorah Luci Costa. Op. cit., p. 34-36. 
composto a maioria, apresentaram fundamentos diversos para se chegar àquele resultado. Consequentemente, a ementa não será um verdadeiro espelho dos fundamentos que levaram à decisão colegiada - até porque, conforme já explicitado, muitas vezes inexiste um fundamento do colegiado em si.

Nesse sentido, Vojvodic, Machado e Cardoso abordam um caso em que os próprios Ministros foram obrigados a debater sobre o que havia sido efetivamente decidido depois que o acórdão já tinha sido publicado. Tratase da ADI 2.591, relativa à incidência do Código de Defesa do Consumidor às instituições financeiras. Em razão de uma contradição entre o resultado constante da ata de julgamento e da ementa, foram opostos embargos de declaração, cujo julgamento originou uma nova decisão, em que alguns Ministros levantaram fundamentos diversos daqueles que haviam apontado previamente $^{117}$.

Além disso, houve discussão quanto à ementa original, que, para o relator, expressava as razões unânimes da maioria decisória, enquanto os outros que haviam composto essa maioria não consideravam que o seu voto tinha sido levado em consideração. Com relação a isso, as autoras destacam a discricionariedade do relator para elaborar a ementa e explicam que, diante da dificuldade de identificar as razões de decidir de cada voto, o redator da ementa considera a sua posição como a principal ${ }^{118}$.

A despeito dessa discricionariedade, pode-se criticar facilmente a prática de incluir na ementa apenas os fundamentos levantados pelo primeiro voto vencedor, em detrimento dos demais posicionamentos que compuseram a maioria decisória. Afinal, trata-se de decisão colegiada, em tese fruto de deliberação entre os magistrados. Por outro lado, é compreensível que, diante do atual modelo de julgamento adotado pelo STF, seja extremamente difícil ou até mesmo impossível para o redator do acórdão identificar a ratio decidendi a fim de inclui-la na ementa.

\footnotetext{
117 Ibid. p. 35 .
}

${ }^{118}$ Ibid. p. 35. 
Sendo assim, a deliberação entre os magistrados deve abarcar também o conteúdo da ementa, concretizando, dessa forma, a vinculação da maioria decisória aos fundamentos. Para tanto, é preciso que, desde o início do processo decisório, haja essa preocupação com a redação do precedente que será firmado. Rafael Lorenzo-Fernandez Koatz sugere que, antes mesmo da fase decisional, isto é, antes de se levar o processo a julgamento, o relatório delimite as questões jurídicas que, no caso, constituem alvo de controvérsia e deverão ser debatidas ${ }^{119}$. Assim, pode-se definir de forma clara o(s) objeto(s) da deliberação, eliminando um dos problemas observados em algumas decisões - como ocorreu, por exemplo, no HC 82.424, abordado por Vojvodic, Machado e Cardoso -, a partir do momento em que se estabelece a premissa comum de que todas as manifestações deverão partir.

Koatz defende que a delimitação das questões jurídicas se dê em modelo de perguntas e, desse modo, incumbiria a cada Ministro dar a sua própria resposta a cada uma das indagações ${ }^{120}$. Esse formato, segundo o autor, evitaria que as manifestações de cada julgador divagassem de forma desnecessária, bem como possibilitaria "a identificação mais clara das questões aprovadas pela maioria, que poderão ser organizadas sob um enunciado geral" 121.

O enunciado geral mencionado por Koatz é justamente a tese jurídica da decisão final, isto é, a síntese da conclusão alcançada pela maioria decisória, explicitando-se os fundamentos que levaram ao resultado. $\mathrm{O}$ Código de Processo Civil de 2015, inclusive, por diversas vezes faz alusão à tese jurídica de precedentes firmados em determinados tipos de julgamento, como os recursos especial e extraordinário repetitivos e o incidente de resolução de demanda repetitiva ${ }^{122}$. Nesses dois últimos casos,

\footnotetext{
${ }^{119}$ KOATZ, Rafael Lorenzo-Fernandez. Op. cit., pp. 457-458.

${ }^{120}$ Koatz propõe, ainda, que a votação seja feita por rodadas, cada uma para uma questão jurídica distinta, com possibilidade de sustentação oral pelas partes em cada rodada (Ibid. pp. 460-461).

${ }^{121}$ Ibid. p. 460.

${ }^{122}$ A título ilustrativo, citem-se os artigos $12, \S 2^{\circ}$, inciso II; 311, inciso II; 955, parágrafo único, inciso II; 985; 986; 987, $\S 2^{\circ} ; 988, \S 4^{\circ} ; 1.022$, parágrafo único, inciso I; todos do CPC/2015.
} 
o CPC contém disposições expressas que obrigam a inclusão, no respectivo acórdão, da análise dos fundamentos da tese jurídica firmada ${ }^{123}$.

Isso não é uma prática estranha ao STF. Pelo contrário, em 2014, o Ministro Barroso já propunha que "a ementa do voto seja aprovada pela maioria que sufragou aquele entendimento" 124 , afirmando que haver "uma tese jurídica claramente definida é um passo importante nessa disseminação do precedente" ${ }^{125}$. E, de fato, antes mesmo da promulgação e vigência do atual CPC, é possível encontrar julgados que se preocuparam em inserir um enunciado geral da decisão, havendo também casos em que, durante a sessão de julgamento, os Ministros debateram especificamente acerca da redação dessa síntese conclusiva.

Exemplo disso ocorreu durante o julgamento do RE 631.240, em 03/09/2014 - ou seja, antes da promulgação do atual CPC -, sobre a exigência ou não de requerimento prévio administrativo para a concessão de benefícios previdenciários. O relator Ministro Barroso, ao final da sua manifestação, asseverou que, em observância ao art. 543-A, § $7^{\circ}$, do CPC de $1973^{126}$,"a tese aqui afirmada em repercussão geral é a que se encontra enunciada nos itens 54 e 55 acima e reproduzida na ementa do presente acórdão"127. Posteriormente, como houve debates durante os votos dos Ministros Marco Aurélio e Teori Zavascki, o Ministro Gilmar Mendes sugeriu a colheita de votos com relação à tese proposta pelo relator ${ }^{128}$. Diante dessa sugestão, o Ministro Barroso abriu espaço para que a advogada da parte se manifestasse e, em seguida, houve novo debate relativo à redação em si da tese. É interessante destacar o diálogo travado

\footnotetext{
${ }^{123}$ Trata-se do art. 984, $\S 2^{\circ}$, que estabelece que "o conteúdo do acórdão abrangerá a análise de todos os fundamentos suscitados concernentes à tese jurídica discutida, sejam favoráveis ou contrários", e do art. $1.038, \S 3^{\circ}$, que dispõe que "o conteúdo do acórdão abrangerá a análise dos fundamentos relevantes da tese jurídica discutida".

${ }^{124}$ STF, Rcl 4.335, Rel. Ministro Gilmar Mendes, Brasília, 20 mar. 2014, p. 184.

125 Ibid.

${ }^{126} \mathrm{CPC} / 1973$, art. 543-A, $\S 7^{\circ}$ : “A Súmula da decisão sobre a repercussão geral constará de ata, que será publicada no Diário Oficial e valerá como acórdão”.

${ }^{127}$ STF, RE 631.240, Rel. Ministro Roberto Barroso, Brasília, 03 set. 2014, p. 31.

${ }^{128}$ Ibid. p. 50.
} 
entre os Ministros Barroso e Zavascki durante esse debate, depois que este propôs uma redação mais abrangente:

"O SENHOR MINISTRO LUÍS ROBERTO BARROSO (RELATOR) - Eu, pessoalmente, prefiro a minha, porque é mais fácil de entender e é mais clara. O SENHOR MINISTRO TEORI ZAVASCKI - Penso que a minha é mais abrangente. Por exemplo, a ação de revisão de benefícios: é preciso saber se há resistência ou não há resistência.

O SENHOR MINISTRO LUÍS ROBERTO BARROSO (RELATOR) Normalmente, o Relator conduz o texto. Quando Vossa Excelência é Relator, eu acompanho o seu texto, eu também não concordo sempre com o texto." ${ }^{29}$

Apesar de, em um primeiro momento, parecer que o Ministro Barroso tenha adotado posição mais semelhante à de um relator-decisor ao defender a sua própria proposta, ao final do julgamento, ele abriu novo espaço para deliberação acerca da tese da decisão, comentando que "gostaria de ouvir as [preocupações] do Ministro Teori para ver se eu consigo produzir um texto que harmonize as diferentes visões" ${ }^{130}$. Como não foi possível chegar a uma solução durante a sessão, o relator levou a nova proposta de redação ao plenário na semana seguinte, assentando que havia solicitado ajuda ao Procurador-Geral do INSS e ao Defensor Público da União, para verificar qual seria a melhor solução referente à modulação dos efeitos da decisão ${ }^{131}$ - que também constaria da tese central. A nova redação foi aprovada pela maioria, de modo que a ementa refletiu efetivamente a voz do colegiado.

Outro exemplo se refere ao desconto durante a paralisação em razão de greve no serviço público, analisado no âmbito do RE 693.456. Embora o julgamento tenha sido concluído em 27/10/2016 - isto é, depois da entrada em vigor do atual CPC -, ele foi iniciado anteriormente, em 02/09/2015. Inicialmente, o relator Ministro Dias Toffoli havia proposto uma tese mais extensa, dividida em dois tópicos ${ }^{132}$. Após pedido de vista, o Ministro

\footnotetext{
${ }^{129}$ Ibid. p. 54; grifos no original.

130 Ibid. p. 78.

131 Ibid. p. 82.

${ }^{132}$ Eis a proposta de tese apresentada inicialmente pelo relator: "1. A deflagração da greve por servidor público civil corresponde à suspensão do trabalho e, ainda que a greve não seja abusiva,
} 
Barroso seguiu o voto do relator, contudo propôs outra redação de enunciado, à qual o Ministro Toffoli disse poder aderir ao final, caso sua posição fosse vencedora.

Colhidos os votos dos demais Ministros, com o resultado de seis votos a quatro pelo estabelecimento do desconto por dias não trabalhados como regra geral, deu-se início à votação específica acerca da redação da tese a ser fixada. O Ministro Toffoli declarou, de plano, que adotara a tese sugerida pelo Ministro Barroso ${ }^{133}$, abrindo, em seguida, possibilidade ao advogado da parte de se pronunciar acerca da nova redação. Em sua manifestação, o advogado observou que a tese, tal como proposta, não contemplava a possibilidade de compensação e negociação entre o Poder Público e os grevistas, embora essa possibilidade tenha constado dos votos dos magistrados. Considerando que "o enunciado é que vai vincular" 134 , o causídico pontuou a necessidade de incluir essa previsão de forma expressa no enunciado, enfatizando que "essa tese valerá para o chefe do Executivo federal, estadual e municipal"135 e externando a preocupação de que "se isso não estiver claro, (...) que há possibilidade inclusive de compensação, conforme Vossa Excelência disse, senão, fecha-se a porta" ${ }^{136}$.

O relator solicitou, então, que o Procurador-Geral da República também se pronunciasse, após o que o Ministro Barroso propôs uma nova redação que abarcava as considerações do advogado. Essa nova redação foi submetida à votação e foi acolhida pela maioria, da qual também fez parte o

\footnotetext{
como regra geral, a remuneração dos dias de paralisação não deve ser paga. 2 . O desconto somente não se realizará se a greve tiver sido provocada por atraso no pagamento aos servidores públicos civis ou por outras situações excepcionais que justifiquem um afastamento da premissa da suspensão da relação funcional ou de trabalho, tais como aquelas em que o ente da Administração ou o empregador tenha contribuído, mediante conduta recriminável, para que a greve ocorresse ou em que haja negociação sobre a compensação dos dias parados ou mesmo o parcelamento dos descontos" (STF, RE 693.456, Rel. Ministro Dias Toffoli, Brasília, 27 out. 2016, p. 166).

133 A redação original da proposta de tese do Ministro Barroso assim determinava: "A administração pública deve proceder ao desconto dos dias de paralisação decorrentes do exercício do direito de greve pelos servidores públicos, em virtude da suspensão do vínculo funcional que esta importa. O desconto será, contudo, incabivel se ficar demonstrado que a greve foi provocada por conduta ilícita do Poder Público" (Ibid. p. 124).

${ }^{134}$ Ibid. p. 167.

${ }^{135}$ Ibid. p. 168.

${ }^{136}$ Ibid.
} 
Ministro Ricardo Lewandowski que, embora tenha seguido a divergência com relação ao mérito, reconheceu que "a tese reflete fielmente aquilo que foi decidido pela maioria"137. O enunciado final ${ }^{138}$, portanto, resultou de franco debate ${ }^{139}$, tendo sido capaz de expressar a ratio decidendi da decisão colegiada, além de ter sido objeto de contraditório - o que contribuiu para o seu aperfeiçoamento.

Em ambos os casos relatados, tratava-se de recurso extraordinário com repercussão geral reconhecida, cujo análise, pela prática recente do STF, tem incluído a fixação de uma tese - muito embora algumas teses transmitam apenas o resultado da decisão, sem apresentar os seus fundamentos ${ }^{140}$. Ademais, nem sempre o enunciado geral desses recursos será fruto de verdadeira deliberação. Primeiramente, destaca-se que a maioria dos Ministros, quando atuam como relatores, propõem uma tese quanto ao mérito no momento de sua manifestação acerca da existência ou não de repercussão geral no plenário virtual ${ }^{141}$. Quando os demais Ministros incluem seu voto no placar virtual, devem apenas preencher três colunas, quais sejam, (i) questão constitucional, (ii) repercussão geral e (iii) reafirmação de jurisprudência, informando tão somente se "hâ" ou "não hâ" cada um dos três aspectos. Assim, não há como saber se, no momento em que um Ministro considera que existe repercussão geral, ele adere ou não à tese de mérito proposta pelo relator.

\footnotetext{
${ }^{137}$ Ibid. p. 174.

138 Eis a sua redação: "A administração pública deve proceder ao desconto dos dias de paralisação decorrentes do exercício do direito de greve pelos servidores públicos, em virtude da suspensão do vínculo funcional que dela decorre, permitida a compensação em caso de acordo. $O$ desconto será, contudo, incabivel se ficar demonstrado que a greve foi provocada por conduta ilícita do Poder Público" (Ibid.)

${ }^{139}$ Houve intervenção também por parte do Ministro Edson Fachin, que propôs alteração da redação da tese, ainda que tenha restado vencido (Ibid. pp. 170-171).

${ }^{140}$ Nesse caso, aplica-se a mesma crítica formulada por Fábio Carvalho Leite e Marcelo Santini Brando no tocante aos enunciados de súmula (v. nota de rodapé $\mathrm{n}^{\circ} 112$ ). Como exemplo, citem-se os enunciados das teses fixadas no bojo dos temas 959 (RE 1.038.925): "É inconstitucional a expressão "e liberdade provisória", constante do caput do artigo 44 da Lei no 11.343/2006"; e 972 (ARE 1.052.700): "É inconstitucional a fixação ex lege, com base no art. $2^{\circ}$, \& $1^{o}$, da Lei 8.072/1990, do regime inicial fechado, devendo o julgador, quando da condenação, ater-se aos parâmetros previstos no artigo 33 do Código Penal". A tese firmada no âmbito do tema 937 (ARE 999.425), por outro lado, especifica a ratio decidendi: "Os crimes previstos na Lei $n^{o}$ 8.137/1990 não violam o disposto no art. $5^{\circ}$, inc. LXVII, da Constituição da República".

${ }^{141}$ Nesse sentido, v. notas de rodapé $n^{\circ} 45$ e 54 .
} 
Além disso, não são todos os casos em que, durante a sessão de julgamento em si, os membros do colegiado discutem especificamente a redação da tese de repercussão geral a ser fixada - e que, na maioria das vezes, já havia sido proposta no plenário virtual. No caso da imunidade tributária de livros eletrônicos (RE 330.817), por exemplo, apesar de todos os Ministros terem seguido a posição do relator, apenas o Ministro Fachin consignou expressamente sua concordância com o enunciado proposto pelo relator, Ministro Toffoli. Na ocasião, inclusive, a Ministra Carmen Lúcia, apesar de ter votado pelo desprovimento do recurso tal como os demais, propôs uma redação diferente de tese ${ }^{142}$, sem que tal sugestão tenha sido levada em consideração.

Com relação aos outros tipos de ação, nomeadamente as ações de controle concentrado, ainda não há a prática recorrente de se fixar uma tese da decisão que sintetize as razões de decidir do Tribunal. Nada obstante isso, existem casos em que houve deliberação específica relativa à redação do enunciado geral. A título ilustrativo, cite-se a ADI 4.815, acerca das biografias não autorizadas, julgada em 10/06/2015, durante o período de vacância do CPC de 2015. A relatora Ministra Carmen Lúcia, ao final do seu voto, propôs a fixação de uma tese amparada nos "direitos fundamentais à liberdade de pensamento e de sua expressão, de criação artística, produção científica" ${ }^{143}$ e dividida em duas partes. Na primeira parte, declarava-se "inexigível autorização de pessoa biografa relativamente a obras ou audiovisuais" ${ }^{144}$, estendendo-se tal inexigibilidade para "pessoas retratadas como coadjuvantes (ou de seus familiares, em caso de pessoas falecidas ou ausentes)"145. Já na segunda parte, a Ministra propusera incluir a ressalva de que a inexigibilidade de autorização era

\footnotetext{
${ }^{142}$ Enquanto o Ministro Toffoli havia sugerido a tese "a imunidade tributária constante do art. 150, VI, $d$, da CF/88 aplica-se ao livro eletrônico (e-book), inclusive aos suportes exclusivamente utilizados para fixá-lo", a Ministra Carmen Lúcia propôs a seguinte redação: "a imunidade tributária prevista na al. d do inc IV do art. 150 da Constituição da República alcança suportes físicos ou imateriais utilizados na veiculação de livro eletrônico, em todas as suas mídias" (STF, RE 330.817, Rel. Ministro Dias Toffoli, Brasília, 08 mar. 2017, p. 3 e p. 93).

${ }^{143}$ STF, ADI 4.815, Rel. Ministra Carmen Lúcia, Brasília, 10 jun. 2015, p. 3.

${ }^{144}$ Ibid.

${ }^{145}$ Ibid.
} 
constitucional sem embargo de indenização, nos termos do art. $5^{\circ}$, inciso X, da Constituição Federal ${ }^{146}$. Entretanto, em sua manifestação, o Ministro Gilmar Mendes questionou a inclusão no enunciado de uma referência expressa à reparação mediante indenização, visto que existem outras formas de reparação, como a republicação da obra. Esse questionamento desencadeou um pequeno debate entre os Ministros, que, por fim, concordaram que seria melhor adotar uma postura minimalista, de modo a explicitar apenas a constitucionalidade da inexigibilidade de autorização para a publicação de biografias ${ }^{147}$. Nesse caso, portanto, observa-se que a tese final firmada pelo STF, além de ter resumido a ratio decidendi da decisão, foi fruto de efetiva deliberação.

Por outro lado, há casos de controle concentrado em que, apesar de constar expressamente da ementa "tese de julgamento", o enunciado ali expresso não foi objeto de deliberação pela maioria. Na ADC 41, em que se discutiu a reserva de vagas para negros em concurso público, por exemplo, embora o resultado tenha sido unânime e os fundamentos levantados pelos magistrados se assemelhassem, alguns votos propuseram teses com diferenças substanciais se comparadas com o enunciado fixado pelo relator, Ministro Barroso. Enquanto o relator, por exemplo, limitou-se a afirmar ser "legítima a utilização, além da autodeclaração, de critérios subsidiários de heteroidentificação, desde que respeitada a dignidade da pessoa humana e garantidos o contraditório e a ampla defesa"148, o Ministro Alexandre de

\footnotetext{
${ }^{146}$ CRFB, art. 5, inciso X: "são invioláveis a intimidade, a vida privada, a honra e a imagem das pessoas, assegurado o direito a indenização pelo dano material ou moral decorrente de sua violação".

147 STF, ADI 4.815, Rel. Ministra Carmen Lúcia, Brasília, 10 jun. 2015, pp. 231-240. Eis a redação final da tese da decisão: "Ação direta julgada procedente para dar interpretação conforme à Constituição aos arts. 20 e 21 do Código Civil, sem redução de texto, para, em consonância com os direitos fundamentais à liberdade de pensamento e de sua expressão, de criação artística, produção científica, declarar inexigível autorização de pessoa biografada relativamente a obras biográficas literárias ou audiovisuais, sendo também desnecessária autorização de pessoas retratadas como coadjuvantes (ou de seus familiares, em caso de pessoas falecidas ou ausentes)".

${ }^{148}$ Eis o inteiro teor da tese proposta pelo relator: "É constitucional a reserva de $20 \%$ das vagas oferecidas nos concursos públicos para provimento de cargos efetivos e empregos públicos no âmbito da administração pública direta e indireta. É legítima a utilização, além da autodeclaração, de critérios subsidiários de heteroidentificação, desde que respeitada a dignidade
} 
Moraes entendeu que "é mandatória a realização de fase apuratória da veracidade das declarações dos candidatos interessados em concorrer às vagas reservadas aos negros", acrescentando, ainda, que "deve ser priorizada a avaliação de natureza documental, fundada em fotografias e documentos públicos, figurando a entrevista como opção residual"149. O Ministro Fachin, por sua vez, apresentou uma fórmula própria, com três tópicos ${ }^{150}$, definindo expressamente que a decisão se aplicava à esfera federal; já o Ministro Fux, embora não tenha proposta nenhum enunciado específico, destacou que a decisão deveria ser aplicada a todos os entes federativos ${ }^{151}$.

Em suma, a despeito da preocupação já existente de se firmar um enunciado geral que servirá como precedente com força vinculante, trata-se ainda de uma prática em construção, que precisa ser difundida e solidificada, não só nos recursos extraordinários com repercussão geral reconhecida, como também nos demais casos. Não basta fixar um enunciado geral; é preciso que esse enunciado reflita os fundamentos da decisão e, principalmente, que haja efetiva deliberação especificamente com relação à sua redação, que, futuramente, será a principal fonte de jurisprudência. Afinal, se a tese da decisão espelha as razões de decidir do Tribunal - e não de um único julgador -, é necessário que todos os seus membros construam conjuntamente o texto que espelhará a voz da instituição.

da pessoa humana e garantidos o contraditório e a ampla defesa" (STF, ADC 41, Rel. Ministro Roberto Barroso, Brasília, 08 jun. 2017, p. 3).

${ }^{149}$ Ibid. p. 86.

${ }^{150} \mathrm{O}$ Ministro Fachin julgou a ação procedente para “( $i$ ) dar interpretação conforme a Constituição do art. $2^{\circ}$, caput e parágrafo único, da Lei 12.990/2014, para assentar a necessidade de estabelecimento de mecanismos de controle de fraudes nas autodeclarações dos candidatos nos concursos públicos federais; (ii) dar interpretação conforme a Constituição do art. $1^{\circ}$ da Lei 12.990/2014, para esclarecer que a política de cotas raciais de que trata a lei se aplica a todos os órgãos e instituições públicas federais, incluindo aquelas dotadas de autonomia em face do Poder Executivo Federal; (iii) dar interpretação conforme a Constituição do art. $4^{\circ}$ da Lei 12.990/2014, para estabelecer que a ordem de classificação estabelecida no preceito se aplica não apenas à nomeação, mas deve também incidir sobre todas as demais dimensões da vida funcional dos servidores públicos cotistas" (Ibid. pp. 105-106).

${ }^{151}$ Ibid. p. 122. 
Essa construção será facilitada se todos partirem das mesmas premissas, manifestando-se sobre as questões jurídicas identificadas previamente pelo relator - conforme sugerido por Koatz. Decididas as questões jurídicas controversas, com base nas quais será fixado o enunciado geral, nada mais natural que o conteúdo da ementa retrate tanto a deliberação acerca de cada uma dessas questões quanto a tese jurídica final da decisão. Isso permitirá que se identifique com mais precisão o estado de jurisprudência do STF acerca das matérias analisadas, possibilitando maior harmonia e precisão na aplicação de seus precedentes, além de fazer o Tribunal se aproximar mais do ideal de corte deliberativa. 


\section{Conclusão}

O crescente protagonismo do STF na sociedade brasileira abriu portas para estudos mais aprofundados acerca do seu modo de decidir. Esses estudos logo evidenciaram as falhas do Tribunal que levam à falta de deliberação nos seus julgamentos: votos cada vez mais extensos, sendo muitos deles elaborados com antecedência; sessões de julgamento que mais parecem sessões de leituras, tomando muitas horas em determinados casos; a ausência de efetivo diálogo entre as manifestações, o que acarreta problemas ainda maiores como a dificuldade de se identificar as razões de decidir do Tribunal - o que, consequentemente, dificulta a aplicação dos seus precedentes.

Nessa monografia, buscou-se analisar essas práticas do STF à luz do ideal de corte deliberativa desenhado por Conrado Hübner Mendes, tendose chegado à conclusão de que a Corte Suprema brasileira, atualmente, não obedece aos padrões exigentes em nenhuma das fases do processo deliberativo, quais sejam, pré-decisional, decisional e pós-decisional. $\mathrm{Na}$ primeira etapa - que envolve tanto os membros do colegiado quanto interlocutores da sociedade -, a despeito da maior abertura do STF ao instituto do amicus curiae, ainda é preciso que haja verdadeira interação entre o Tribunal e as instituições que desejam colaborar na sua decisão, a fim de que as intervenções de amici curiae não se tornem meros instrumentos de reforço argumentativo, mas sim de um franco debate de ideias e posições.

$\mathrm{Na}$ fase decisional, de interação colegiada, é evidente a postura individualista tanto do relator quanto dos demais Ministros durante a sessão de julgamento. Além das práticas já mencionadas, como os extensos votos e a elaboração de manifestações anteriormente à sessão, a atitude individualista é espelhada na própria estrutura de cada voto, que costuma utilizar um número muito mais elevado de citações e referências favoráveis em detrimento das opiniões contrárias à que se defende. Ao invés de 
magistrados, portanto, o que existem são onze advogados que buscam defender a própria posição - posição esta que, nos casos moralmente mais sensíveis, tem mais chance de ter sido adotada, no contexto da descoberta, com base em atalhos fornecidos pelo sistema intuitivo e não pelo sistema deliberativo.

Isto é, justamente nos casos em que os Ministros costumam munir-se de extensos votos, com múltiplas citações e referências a seu favor, estudos da Teoria do Direito que aplicam conceitos da psicologia experimental demonstram que, tratando-se de matéria que também envolve questões de cunho moral, é mais provável que essa decisão seja tomada com base em heurísticas. Essas heurísticas, por sua vez, podem ser engatilhadas por fatores internos ou externos ao caso a ser julgado. A fundamentação jurídica, portanto, não atuará no contexto da descoberta - isto é, no âmbito da tomada de decisão -, mas sim no contexto da justificação, por meio do sistema deliberativo, que figurará como mero advogado do sistema intuitivo.

Armado com amplo material legal, doutrinário e jurisprudencial, o relator adotará, via de regra, a postura de um relator-decisor, que busca defender a própria posição, ao invés de um relator-articulador, cuja função seria procurar estimular todos os membros a chegar a uma solução conjunta. Os demais Ministros, por sua vez, quando elaboram previamente sua manifestação de forma estruturada e embasada em farto material favorável à sua opinião, dificilmente serão convencidos por outros argumentos. Por outro lado, em casos meramente repetitivos e sem repercussão, seguirão o relator sem nenhuma consideração - a denominada manifestação sem declaração de voto.

Consequentemente, a redação final do inteiro teor do acórdão não será deliberativa, justamente em razão da ausência de deliberação na fase anterior. Diante disso, nos casos em que apenas o relator tiver se pronunciado, a ratio decidendi será resumida tão somente às razões expostas pelo relator, enquanto nos casos de maior repercussão, em que 
todos se pronunciam por meio de extensos votos com pouco ou nenhum diálogo entre eles, o efeito será a dificuldade de identificar as razões de decidir do Tribunal como instituição colegiada. Isso se deve principalmente à regra de que, para solucionar um caso, basta a composição de uma maioria em torno do resultado, sem vinculação alguma com relação aos fundamentos da decisão.

Não sendo possível identificar a ratio decidendi, o responsável por redigir a ementa - que será ou o relator ou o Ministro que tiver proferido o primeiro voto vencedor - incluirá apenas os seus próprios fundamentos, muitas vezes ignorando os argumentos levantados por seus pares. Desse modo, torna-se muito difícil ao aplicador do direito e aos próprios membros do STF apontar a jurisprudência do Tribunal acerca de determinada matéria, o que dificulta a própria aplicação dos precedentes.

A partir dessas falhas de deliberação, procurou-se tecer algumas propostas que poderiam ser implementadas pelo Tribunal, tendo-se em mente, também, a realidade fática da sobrecarga de processos. A fim de permitir maior precisão nos julgamentos, é preciso que todos os magistrados partam da mesma premissa - que, por sua vez, deve ser delimitada no relatório, em que constarão as questões jurídicas controversas relativas à matéria identificadas pelo próprio relator. Caberá, assim, a cada Ministro responder de forma clara a cada uma das questões apontadas. Durante a sessão de julgamento, é importante que o tamanho das manifestações seja reduzido, eliminando-se divagações desnecessárias. Para tanto, melhor seria que nenhum Ministro além do relator estruturasse seu próprio voto com antecedência, podendo, se for o caso, efetuar pesquisas previamente e levá-las em notas - o que seria facilitado se todos os relatores adotasses a prática de distribuir seu voto com antecedência. Essas pequenas mudanças, além de proporcionarem maior abertura ao diálogo, reduzem o tempo despendido por cada julgador antes e durante a sessão.

É essencial privilegiar mais debates orais e menos intervenções personalistas, a fim de que os membros cheguem efetivamente a uma 
posição do colegiado, o que pode e deve ser estimulado pelo relator, por meio de uma atitude de relator-articulador. Deve haver uma preocupação não só com o resultado, mas também com a fundamentação, resumindo-a em um enunciado geral para identificar as razões de decidir do Tribunal, em uma redação construída de forma deliberativa. Incluindo-se tanto as respostas às questões jurídicas controversas quanto o enunciado geral - a tese jurídica da decisão - na ementa, será mais fácil identificar a ratio decidendi e aplicar os precedentes do STF.

Para que essas propostas sejam aplicadas, contudo, é necessário que cada Ministro se reconheça como membro de um colegiado, assumindo um compromisso perante a própria instituição em detrimento de suas próprias visões. Isso implica uma postura mais colaborativa do que persuasiva, assim como a aceitação de que posições diferentes da sua podem se mostrar melhores a determinado caso - o que só será possível entender em um ambiente de efetiva cooperação colegiada. Essa aceitação deve perpassar também pela consciência de que a tomada de uma decisão, principalmente em casos moralmente mais sensíveis, pode ser engatilhada por fatores completamente alheios ao âmbito jurídico, ainda que se tenha encontrado uma roupagem jurídica para justificar a posição adotada inicialmente.

Não se ignora que existem muitos outros fatores que não foram analisados nessa monografia e que também precisam ser equacionados ou solucionados, como, por exemplo, os efeitos da transmissão televisiva das sessões de julgamento do plenário, as possibilidades de atuação monocrática dos Ministros na posição de relatores, as repercussões dos pedidos de vista, a influência do contexto político sobre as decisões do STF, o enorme volume de processos em paralelo ao atual sistema recursal brasileiro, entre outros. As propostas aqui levantadas, todavia, representariam um passo pequeno, mas significativo, rumo à construção de uma corte constitucional mais deliberativa e, portanto, mais legítima. 


\section{Referências bibliográficas}

ALMEIDA, Danilo dos Santos; BOGOSSIAN, Andre Martins. "Nos termos do voto do relator": considerações acerca da fundamentação coletiva nos acórdãos do STF. REI - Revista Estudos Institucionais, Revista da Faculdade Nacional de Direito da UFRJ. Rio de Janeiro, vol. 2, 1, pp. 263297, 2016.

ARGUELHES, Diego Werneck. Afinal, ministro do Supremo é magistrado?. JOTA, 15 mar. 2016. Disponível em https://bit.ly/2KPvmoY. Acesso em 22 mai. 2018.

ARGUELHES, Diego Werneck; RIBEIRO, Leandro Molhano. O Supremo Individual: mecanismos de influência direta dos Ministros sobre o processo político. Direito, Estado e Sociedade, Revista do Departamento de Direito da PUC-Rio. Rio de Janeiro, n. 46, pp. 121-155, 2015.

ARGUELHES, Diego Werneck; RIBEIRO, Leandro Molhano. Quando a unanimidade não esclarece. Valor Econômico, Rio de Janeiro, 22 jun. 2012.

BRANDO, Marcelo Santini. Como decidem os juízes? Uma investigação da teoria realista da decisão judicial a partir das contribuições das ciências cognitivas e da psicologia moral. Rio de Janeiro, 2013. Dissertação (Mestrado em Direito). Departamento de Direito da PUC-Rio.

BRASIL. Teses de Repercussão Geral. Supremo Tribunal Federal. Disponível em: https://bit.ly/2KMGT8u. Acesso em 22 mai. 2018

DIMOULIS, Dimitri. A Constituição interpretada sem regras. In: FALCÃO, Joaquim (Org.); ARGUELHES, Diego Werneck (Org.); FREIRE, Felipe Recondo. (Org.). Onze Supremos: O Supremo em 2016. Rio de Janeiro: Letramento, pp. 63-65, 2017.

FALCÃO, Joaquim; ARGUELHES, Diego Werneck. Onze Supremos: todos contra o plenário. In: FALCÃO, Joaquim (Org.); ARGUELHES, Diego Werneck (Org.); FREIRE, Felipe Recondo. (Org.). Onze Supremos: O Supremo em 2016. Rio de Janeiro: Letramento, pp. 20-28, 2017.

GOMES, Juliana Cesario Alvim; ARGUELHES, Diego Werneck. Qual o papel do relator no Supremo? Duas respostas em tensão no caso da pederastia. JOTA, 03 nov. 2015. Disponível em https://bit.ly/2IHanYT. Acesso em 22 mai. 2018.

HAIDT, Jonathan. The Emotional Dog and Its Rational Tail: A Social Intuitionist Approach to Moral Judgment. Psychological review, vol. 108, n. 4, pp. 814-834, 2001. 
HAIDT, Jonathan; BJORKLUND, Fredrik. Social Intuitionists Answer Six Questions About Moral Psychology. In: W. Sinnott-Armstrong (Ed.). Moral psychology. Vol. 2: The cognitive science of morality. Cambridge, MA: MIT Press, pp. 181-217, 2006.

HOUAISS, Antônio; VILLAR, Mauro de Salles; FRANCO, Francisco Manoel de Mello. Dicionário Houaiss da Língua Portuguesa. $1^{\mathrm{a}}$ ed. Rio de Janeiro: Objetiva, 2001.

KOATZ, Rafael Lorenzo-Fernandez. Deliberação e procedimento no Supremo Tribunal Federal: propostas para um modelo de deliberação compatível com a Constituição de 1988. In BAPTISTA, Patrícia (Org.); BRANDÃO, Rodrigo (Org.). Coleção Direito UERJ 80 Anos - Direito Público. Rio de Janeiro: Freitas Bastos, v. 8, pp. 451-472, 2015.

LEITE, Fábio Carvalho; BRANDO, Marcelo Santini. Dispersão de fundamentos no Supremo Tribunal Federal. Direito, Estado e Sociedade: Revista do Departamento de Direito da PUC-Rio. Rio de Janeiro, n. 48, p. 139-166, 2016.

LEITE, Fábio Carvalho; HANNIKAINEN, Ivar Allan Rodriguez. $O$ uso de experimentos na pesquisa jurídica: experiências com a liberdade de expressão. Rio de Janeiro: no prelo, 2018.

MENDES, Conrado Hübner. O Projeto de uma Corte Deliberativa. In: VOJVODIC, Adriana (Org.); PINTO, Henrique Motta (Org.); GORZONI, Paula (Org.); SOUZA, Rodrigo Pagani de (Org.). Jurisdição Constitucional no Brasil. São Paulo: Malheiros Editores, pp. 53-74, 2012.

MENDES, Conrado Hübner. Onze ilhas. Folha de S. Paulo, Tendências e Debates, $01 \mathrm{fev}$. 2010. Disponível em https://bit.ly/2GwPviF. Acesso em 22 mai. 2018.

SILVA, Virgílio Afonso da. 'Um Voto Qualquer'? O papel do ministro relator na deliberação no Supremo Tribunal Federal. REI - Revista Estudos Institucionais: Revista da Faculdade Nacional de Direito da UFRJ, v. 1, p. 180-200, 2015.

SILVA, Virgílio Afonso da. O relator dá voz ao STF? Uma réplica a Almeida e Bogossian. REI - Revista Estudos Institucionais: Revista da Faculdade Nacional de Direito da UFRJ, v. 2, p. 648-669, 2016.

SILVA, Virgílio Afonso da. De Quem Divergem os Divergentes: os Votos Vencidos no Supremo Tribunal Federal. Direito, Estado e Sociedade: Revista do Departamento de Direito da PUC-Rio, n. 47, p. 205-225, 2015. 
SILVA, Virgílio Afonso da. Deciding Without Deliberating. International Journal of Constitutional Law, Oxford University Press, v. 11, p. 557-584, 2013.

STF, ADPF 54, Rel. Ministro Marco Aurélio, Brasília, 12 abr. 2012.

STF, ADI 3.510, Rel. Ministro Ayres Britto, Brasília, 29 mai. 2008.

STF, AP 470 / AgR, Rel. Ministro Joaquim Barbosa, Brasília, 17 dez. 2012.

STF, ADPF 378 / MC, Rel. Ministro Edson Fachin, Redator do Acórdão: Ministro Roberto Barroso, Brasília, 17 dez. 2015.

STF, AC 4.070 / Ref, Rel. Ministro Teori Zavascki, Brasília, 05 de mai. 2016.

STF, AC 4.327 / AgR-terceiro-AgR, Rel. Ministro Marco Aurélio, Redator do Acórdão: Ministro Roberto Barroso, Brasília, 26 set. 2017.

STF, ADI 4.650, Rel. Ministro Luiz Fux, Brasília, 17 set. 2015.

STF, ADI 4.277 / ADPF 132, Rel. Ministro Ayres Britto, Brasília, 05 mai. 2011.

STF, ADC 41, Rel. Ministro Roberto Barroso, Brasília, 08 jun. 2017.

STF, ADI 4.983, Rel. Ministro Marco Aurélio, Brasília, 06 out. 2016.

STF, ADI 4.815, Rel. Ministra Carmen Lúcia, Brasília, 10 jun. 2015.

STF, Rcl 4.335, Rel. Ministro Gilmar Mendes, Brasília, 20 mar. 2014.

STF, HC 126.292, Rel. Ministro Teori Zavascki, Brasília, 17 fev. 2016.

STF, RE 693.456, Rel. Ministro Dias Toffoli, Brasília, 27 out. 2016.

STF, RE 330.817, Rel. Ministro Dias Toffoli, Brasília, 08 mar. 2017.

STF, ADPF 291, Rel. Ministro Roberto Barroso, Brasília, 28 out. 2015.

STF, HC 82.424, Rel. Ministro Moreira Alves, Brasília, 17 set. 2003.

STF, ADI 1.969, Rel. Ministro Ricardo Lewandowski, Brasília, 28 jun. 2007. 
STF, HC 152.752, Rel. Ministro Edson Fachin, Brasília, 05 abr. 2018.

STF, ADI 2.591, Rel. Ministro Carlos Velloso, Redator do Acórdão: Ministro Eros Grau, Brasília, 07 jun. 2006.

STF, RE 631.240, Rel. Ministro Roberto Barroso, Brasília, 03 set. 2014.

STRUCHINER, Noel. Aplicação e Conseqüências da Noção de Textura Aberta da Linguagem para a Filosofia do Direito. In: I SAF-PUC, 2001, Rio de Janeiro. AnaLógos - Anais da I SAF-PUC. Rio de Janeiro: Booklink, pp. 92-100, 2001.

STRUCHINER, Noel; SHECAIRA, Fábio P. Teoria da Argumentação Jurídica. Rio de Janeiro: Contraponto / Editora PUC-Rio, 2016, 184 p.

SUNDFELD, Carlos Ari; PINTO, Henrique Motta. Três Desafios para Melhorar a Jurisdição Constitucional Brasileira. In: VOJVODIC, Adriana (Org.); PINTO, Henrique Motta (Org.); GORZONI, Paula (Org.); SOUZA, Rodrigo Pagani de (Org.). Jurisdição Constitucional no Brasil. São Paulo: Malheiros Editores, pp. 19-52, 2012.

SUNDFELD, Carlos Ari; SOUZA, Rodrigo Pagani de. Accountability e Jurisprudência do STF: Estudo Empírico de Variáveis Institucionais e Etrutura das Decisões. In: VOJVODIC, Adriana (Org.); PINTO, Henrique Motta (Org.); GORZONI, Paula (Org.); SOUZA, Rodrigo Pagani de (Org.). Jurisdição Constitucional no Brasil. São Paulo: Malheiros Editores, pp. 75116, 2012.

VOJVODIC, Adriana de Moraes; MACHADO, Ana Mara França; CARDOSO, Evorah Luci Costa. Escrevendo um romance, primeiro capítulo: precedentes e processo decisório no STF. Revista Direito $G V$, São Paulo, v. 9, pp. 21-44, 2009.

S.N. Leia voto Ministra Rosa Weber. Revista Consultor Jurídico. Disponível em https://bit.ly/2kjek71. Acesso em 22 mai. 2018.

S.N. Marco Aurélio vê sua homenagem como "estímulo", Revista Consultor Jurídico, 06 jul. 2010. Disponível em https://bit.ly/2GJTgzM. Acesso em 22 mai. 2018.

S.N. Ministro Marco Aurélio: "Plenário virtual não é plenário, o sentido de colegiado é a troca de ideias". Migalhas, 04 jul. 2016. Disponível em https://bit.ly/2x6VDgf. Acesso em 22 mai. 2018. 